\title{
Osmanlı Sosyal Hayatında Seyyidler: \\ 18. ve 19. yy. Diyarbekir Örneği
}

\author{
Ümit Güler \\ Doç. Dr., Batman Üniversitesi, İslami İlimler Fakültesi, İslâm Tarihi Ana Bilim Dalı \\ Batman/Türkiye \\ umit.guler@batman.edu.tr \\ https://orcid.org/0000-0002-0828-4197
}

Öz: Hz. Peygamber'in soyunu devam ettiren kızı Hz. Fatıma ile Hz. Ali'nin nesline seyyid ve şerif unvanları verilir. Osmanlı'da Hüseynîler'in seyyid, Hasenîler'in şerif olarak adlandırıldıkları yönünde yaygın bir bilgi bulunsa da bu doğru bir genelleme değildir. Zira bu dönemde Hz. Hasan ve Hz. Hüseyin'in nesliyle ilgili net bir ayrım söz konusu olmamıştır. Mamafih Osmanlı Diyarbekiri'nde de hem Hz. Hasan hem de Hz. Hüseyin'in nesline seyyid unvanı verilmiş ve şerif tabiri kullanılmamıştır. Seyyidler, toplumsal rolleri ve konumları itibariyle Osmanlı sosyal tarihinin en önemli konularından biridir. Bu çalışmanın amacı, 18. ve 19. yüzyıl Diyarbekir şer'iyye sicilleri ve ahkâm defterlerinden hareketle seyyidlerin sosyal hayatlarına ışık tutmaktır. Araştırmada toplumsal konum ve rollerine bağlı olarak seyyidlerin sosyal hayattaki görünürlüklerinin yüksek olduğu tespit edilmiş; bu dönemde seyyidlerin, oldukça etkili mesleki ve sosyal sahalarda varlık gösterdikleri anlaşılmıştır. Seyyidler umumiyetle, toplum içerisinde saygın ve seçkin bir konumda yer almakla birlikte Hz. Peygamber'in soyunu temsil etmeleri itibariyle taşıdıkları manevi sorumluluğa muvafık bir yaşam tarzına sahip olmuşlardır.

Anahtar Kelimeler: İslam Tarihi, Seyyidler, Osmanlı Sosyal Hayatı, Şerif, Diyarbekir.

Geliş Tarihi/Received Date: 16.01 .2021

Kabul Tarihi/Accepted Date: 04.05.2021

\section{Araştırma Makalesi/Research Article}

Atıf/Citation: Güler, Ümit "Osmanlı Sosyal Hayatında Seyyidler: 18. ve 19. yy. Diyarbekir Örneği”. Uludă̆ Üniversitesi İlahiyat Fakültesi Dergisi 30/1 (Haziran 2021), 185-221. https://doi.org/ 10.51447/uluifd.862322 


\title{
Sayyids in the Ottoman Social Life: The Case of Diyarbekir in the 18th and 19th Centuries
}

\begin{abstract}
The generation of Hz. Fatıma, daughter of the Prophet Muhammad, and Hz. Ali who continue lineage of the Prophet Muhammad is entitled as sayyid and sheriff. Although there is widespread information that the Husaynis were called sayyids and the Hasenis as sheriff in the Ottoman Empire, it is not an accurate generalization. Because there was no clear distinction regarding the lineage of $\mathrm{Hz}$. Hasan and Hz. Hüseyin in this period. However, in the Ottoman Diyarbekir, the generation of both Hz. Hasan and Hz. Hüseyin was entitled sayyid, and the term sheriff was not used. Sayyids are among the most important subjects of the Ottoman social history by their social roles and positions. The aim of this study was to shed light on the social life of the sayyids based on Diyarbekir court records and judgement records in the 18th and 19th centuries. In the study, it was determined that sayyids' visibility in social life was quite high depending on their social position and roles, and it was found out that the sayyids had a very effective presence in professional and social fields. Although Sayyids largely had a reputable and distinguished position in society, they had a lifestyle which was consistent with the spiritual responsibility they bore since they represented the lineage of the Prophet Muhammad.
\end{abstract}

Keywords: Islamic History, Sayyids, Ottoman Social Life, Sheriff, Diyarbekir.

[You may find an extended abstract of this article after the bibliography.]

\section{Giriş}

Seyyid (çoğ. sâdât) kelimesi sözlükte "efendi, bey, önder" gibi anlamlara gelir ve Hz. Peygamber'in hadislerinde de sözlük anlamlarıyla sıkça kullanılır. ${ }^{1}$ Nitekim Hz. Peygamber'in Hz. Hasan ve Hz. Hüseyin'i “seyyid” olarak andığı birçok rivayet bulunmaktadır. ${ }^{2}$

Terim anlamı itibariyle seyyid, Hz. Peygamber'in Hz. Ali ile Fâtıma'dan doğan torunlarıyla onların soyundan gelenleri ifade eden bir unvandır. ${ }^{3}$ Literatürde seyyid unvanının özel olarak Hz. Hüseyin'in, şerif unvanının da Hz. Hasan'ın soyundan gelenleri ifade ettiği yönünde bir bilgi bulunsa $\mathrm{da}^{4}$ bu genelleme yanlıştır. Zira tarihte seyyid ve şerif unvanları aynı bölgede değișik zamanlarda veya aynı zamanda farklı

1 Mustafa Sabri Küçükaşçı, "Seyyid”, Türkiye Diyanet Vakfi İslâm Ansiklopedisi, (İstanbul: TDV Yayınları, 2009), 37/40.

2 Mithat Eser, Abbasilerin Illk Döneminde Seyyidler ve Şerifler (İstanbul: İz Yayıncllık, 2014), 18.

3 Küçükaşç1, "Seyyid", 37/40.

4 Eser, Abbasilerin Illk Döneminde Seyyidler ve Şerifler, 19; İsmail Hakkı Uzunçarşıll, "Osmanlılar'da Nakîbü'l-Eşrafllk", haz. Ali Dadan, Marife, 3 (2004), 431. 
bölgelerde birbirlerinin yerine kullanılmıştır, bu cihetle aralarında net ve kesin bir ayrım bulunmamaktadır. ${ }^{5}$

Şerif (çoğ. eşrâf veya şürefâ) kelimesi, sözlükte "şerefli, asil soylu, mübarek" gibi anlamlara gelmektedir. ${ }^{6}$ Cahiliye döneminde seyyid ve șerif kelimeleri birbirine yakın anlamlarda kullanılmıştır. Yukarıda da temas edildiği gibi tarihsel süreçte şerif kelimesinin terim olarak Hz. Hasan'ın soyundan gelenleri ifade ettiği yönünde bir bilgi mevcut olsa da bu hususta belirgin bir ayrım yoktur.?

Hz. Peygamber'in soyunu devam ettiren kızı Hz. Fatıma ile Hz. Ali'nin çocukları ve torunlarına verilen seyyid ve şerif unvanları, Hz. Hasan ile Hüseyin'in dışında Hz. Ali'nin diğer çocukları (özellikle Havle bt. Cafer adlı eşinden dünyaya gelen oğlu Muhammed b. Hanefiyye'nin soyundan gelenler) için de kullanılmıştır. Ancak IV. (X.) yüzyılın sonlarından itibaren seyyid ve şerif unvanları sadece Hz. Hasan ile Hüseyin'in soyundan gelenler için kullanılmaya başlamıştır. ${ }^{8}$

Ülkemizde, seyyidin Hz. Hüseyin'in, şerifin de Hz. Hasan'ın neslinden gelenleri ifade ettiği yönünde yaygın bir bilgi bulunmaktadır ${ }^{9}$ ve bu durum birçok eserde de yer edinmiştir. ${ }^{10}$ Bu kanaatin oluşmasında İsmail Hakkı Uzunçarşıllı'nın "Fatımîler zamanında şerif unvanı Âl-i Fatıma'ya mahsustu, sonraki dönemlerde şerif Hz. Hasan'in, seyyid ise Hz. Hüseyin'in soyundan gelenleri karşılayacak şekilde yaygınlık kazandı ve Türkçe'de Hz. Hasan'ın soyundan gelen kola şerif, Hz. Hüseyin'den gelene seyyid denilmek suretiyle iki kol birbirinden ayrllır."11 şeklinde ifade ettiği görüşü etkili olmuştur. ${ }^{12}$ Bundan sonra daha önceki kaynaklara gitmeyen bazı tarih ve dil

5 Eser, Abbasilerin ilk Döneminde Seyyidler ve Şerifler, 19; Ayhan Işsk, Meşîhat Arşivi Belgeleri Işı̆ğında Seyyidler ve Nakîbü'l-Eşrâfllk Müessesesi (İstanbul: İstanbul Üniversitesi, Sosyal Bilimler Enstitüsü, Doktora Tezi, 2013), 24.

6 Küçükaşç1, "Seyyid", 37/40.

7 Eser, Abbasilerin Illk Döneminde Seyyidler ve Şerifler, 22; Işık, Meşîhat Arşivi Belgeleri Işı̆̆ı̆nda Seyyidler ve Nakîbü'l-Eşrâfllk Müessesesi, 26.

8 Küçükaşç1, "Seyyid", 37/40.

9 Işık, Meşîhat Arşivi Belgeleri Işı̆̆ında Seyyidler ve Nakîbü’l-Eşrâfllk Müessesesi, 25.

10 Mustafa S. Küçükaşçı, “Tarihi Süreçte Seyyid ve Şerif Kavramlarının Kullanımı”, Osmanlı Araştırmaları 33/33 (Haziran 2009), 126.

11 İsmail Hakkı Uzunçarşıll, Mekke-i Mükerreme Emirleri (Ankara: Türk Tarih Kurumu, 1984), 5; Ayrıca bk. İsmail Hakkı Uzunçarşıllı, Osmanlı Devletinin İlmiye Teşkilatı (Ankara: Türk Tarih Kurumu, 2014), 167; Bu görüşün ortaya çıkmasında XX. yüzyılın ortalarından itibaren Hasenî soydan gelen Mekke emirleri için şerif kullanımının yaygınlaşması ile bu iki unvandan şerifin Hasenî, seyyidin ise Hüseynîler'e tahsis edildiği yönünde önceki tarih ve edebiyat kitapları tarafından teyit edilmeyen bir bilginin çıkmasına sebep olduğu belirtilmektedir. Geniş bilgi için bk. Küçükaş̧̧ı "Tarihi Süreçte Seyyid ve Şerif Kavramlarının Kullanımı", 126.

12 Işık, Meşîhat Arşivi Belgeleri Işığında Seyyidler ve Nakîbü'l-Eşrâflk Müessesesi, 28; Küçükaşçı, “Tarihi Süreçte Seyyid ve Şerif Kavramlarının Kullanımı", 126. 
araştırmacılarının bu anlayışı tekrarlamak suretiyle yanlışın yerleşmesine zemin hazırladıkları ifade edilir. ${ }^{13}$ Hâlbuki Osmanlı döneminde Hz. Hasan ve Hz. Hüseyin'in nesliyle ilgili bir ayrım söz konusu olmadığı gibi Hz. Hasan'ın soyu için seyyidlere nispetle şerif denildiği de vaki değildir. ${ }^{14}$ Günümüzde de İslam dünyasının muhtelif birçok bölgesinde seyyid ve şerif unvanlarının birbiri yerine kullanıldığı bilinmektedir. ${ }^{15}$ Mamafih Güneydoğu Anadolu'da hem Hz. Hasan hem de Hz. Hüseyin'in nesline seyyid unvanı verilmektedir. ${ }^{16}$

İncelemiş olduğumuz belgeler Osmanlı Diyarbekiri'nde de kullanımın mezkûr şekilde olduğuna işaret etmektedir. Zira ilgili belgelerde şerif unvanına rastlanmaması, bu bölgelerde şerif unvanının değil de seyyid unvanının kullanıldığına yönelik önemli bir göstergedir.

Çalışmanın amacı, 18. ve 19. yüzyıla ait Diyarbekir şer'iyye sicilleri ve ahkâm defterlerinden hareketle ilgili dönemdeki seyyidlerin sosyal hayatlarına ş̧ık tutmaktır. $\mathrm{Bu}$ amaca istinaden literatürdeki mevcut bilgilerin gereksiz tekrarından kaçınılarak mezkûr belgelerden elde edilen veri, bulgu ve değerlendirmelerin ortaya konulmasına gayret edilecektir. Araştırmanın inceleme bölgesi Diyarbekir ${ }^{17}$ olarak da ifade edilen Âmid kazasıdır. ${ }^{18}$ Osmanlı döneminde Âmid, bugünkü Diyarbakır merkezini ifade etmektedir. ${ }^{19}$

Araştırma, ilgili döneme ait Diyarbekir (Âmid) şer'iyye sicilleri ${ }^{20}$ ve Diyarbekir ahkâm defterlerine ${ }^{21}$ dayanmaktadır. Şüphesiz Osmanlı sosyal tarihinin en önemli

13 Küçükaş̧̧ı, "Tarihi Süreçte Seyyid ve Şerif Kavramlarının Kullanımı”, 126.

14 Işık, Meşîhat Arşivi Belgeleri Işı̆̆ında Seyyidler ve Nakîbü'l-Eşrâflk Müessesesi, 25; Ercan Gümüş, "Sâdât: 17. ve 18. Yüzyılda Diyarbekir Eyaleti'nde Seyyidler, İmtiyazları ve Sosyo-Ekonomik Konumları Hakkında Bir Değerlendirme”, Sosyal, Beşeri ve İdari Bilimler Alanında Yenilikçi Yaklaşımlar, ed. Kürşat Özdaşlı vd., (Ankara: Gece Akademi Yay., 2018), 3/572; Benzer bir değerlendirme için bk. Küçükaşçı, "Tarihi Süreçte Seyyid ve Şerif Kavramlarının Kullanımı", 109.

15 Eser, Abbasilerin Illk Döneminde Seyyidler ve Şerifler, 23; Küçükaşçı, "Tarihi Süreçte Seyyid ve Şerif Kavramlarının Kullanımı", 129.

16 Abdurrahman Adak, “Güneydoğu Anadolu'da Seyyidler”, Marife, 3 (2004), 366.

17 “...Âmid nâm-1 diğer Diyarbekir kazâsı...”, bk. Diyarbekir (Âmid) Şer'iyye Sicilleri (DŞS), 3775, 10b-2.

18 İncelenen sicil ve ahkâm defterlerinde yer alıp bu kazaya ait olmayan belgeler araştırma konusuna dâhil edilmemiştir.

19 İbrahim Yılmazçelik, XIX. Yüzyılın İlk Yarısında Diyarbakır (1790-1840) (Ankara: Türk Tarih Kurumu Yay., 2014), 12

20 Diyarbekir (Âmid) Şer'iyye Sicilleri (DŞS), Başbakanlık Osmanlı Arşivi (BOA), Defter No: 3789, 3828, 3709, 3712, 3754, 3756, 3744, 3714, 3773, 3796, 3743, 3757, 3675, 3753, 3725, 3785, 3823, 3749, 3797, 3798, $3698,3750,3716,3787,3746,3745,3685,3742,3718,3767,3741,3791,3726,3800,3731,3747,3804,3760$, $3768,3803,3707,3680,3702,3774,3775$.

21 Diyarbakır Ahkâm Defterleri (DAD), Başbakanlık Osmanlı Arşivi (BOA), Katalog No: 989, Sıra No: 5, 6, $7,8,9$. 
kaynağını teşkil eden şer'iyye sicilleri ${ }^{22}$ Osmanlı toplumundaki seyyidlerin sosyal hayatlarına ışık tutması bakımından oldukça elverişlidir. Bunun yanı sıra şer'iyye sicilleri kadar zengin olmamakla beraber Diyarbekir ahkâm defterlerinden de aydınlatıcı bilgiler elde edilmiştir.

Osmanlı dönemi seyyid ve şeriflerini konu edinen çalışmalar incelendiğinde mevzunun uzun yıllar boyu ihmal edildiği, Rüya Kılıç'ın doktora tezi olarak hazırlamış olduğu çalışmasının ${ }^{23}$ alanda ciddi bir boşluğu doldurduğu ve son 20 yıldaki araştırmalarda dikkate değer bir artış yaşandığı gözlenmektedir. ${ }^{24}$ Ancak henüz bu alanda

22 Ahmet Akgündüz, Şeri’yye Sicilleri (ìstanbul: Türk Dünyası Araştırmaları Vakfı, 1988), 1/12; Ayrıca bk. Osman Çetin, Sicillere Göre Bursa'da İhtida Hareketleri ve Sosyal Sonuçları (1472-1909) (Ankara: Türk Tarih Kurumu Basımevi, 1994), IX; Yunus Uğur, "Şer'iyye Sicilleri”, Türkiye Diyanet Vakfi İslâm Ansiklopedisi (İstanbul: TDV Yayınları, 2010), 39/8; Şer'iyye sicilleri hakkında geniş bilgi için bk. İsmail Hakkı Uzunçarşıll, "Şerî̀ Mahkeme Sicilleri”, Ülkü Halkevleri Dergisi 5/29 (Temmuz 1935), 365-368; T. Mümtaz Yaman, "Şer'î Mahkeme Sicilleri”, Ülkü Halkevleri Dergisi 12/68 (ilk Teşrin 1938), 153-164.

23 Rüya Kılıç, Osmanlı Devleti’nde Seyyidler ve Şerifler (XIV-XVI. Yüzyllar) (Ankara: Hacettepe Üniversitesi, Sosyal Bilimler Enstitüsü, Doktora Tezi, 2000).

${ }^{24}$ Osmanlı dönemi seyyid ve şeriflerine dair başlıca çalışmalar şunlardır: Necdet Sakaoğlu, "Seyyidlik Sarığı Sarmak", Tarih ve Toplum 5 (1985), 107-108; Rüya Kılıç, Hilafet Mücadelelerinin İslam Tarihinde ve Osmanlı İmparatorluğu'nda Toplumsal Yapıdaki İzdüşümü: Seyyid ve Șerifler (Ankara: Hacettepe Üniversitesi, Sosyal Bilimler Enstitüsü, Yüksek Lisans Tezi, 1994); Ahmet Rıfat Efendi, Osmanlı Toplumunda Sâdât-ı Kirâm ve Nakîbül'-Eşrâflar, haz. Hasan Yüksel, Fatih Köksal (Sivas: y.y. 1998); Rüya Kılıç, Osmanlı Devleti'nde Seyyidler ve Şerifler (XIV-XVI. Yüzylllar) (Ankara: Hacettepe Üniversitesi, Sosyal Bilimler Enstitüsü, Doktora Tezi, 2000); Murat Sarıcık, "Osmanlı Devleti'nde Nakîbü'l-Eşrâflık Kurumu”, Türkler, 10 (Ankara: y.y. 2002), 385-393; Zafer Erginli, “Osmanlı Devleti'nin İlk Resmî Nakîbü'l-Eşrâf' 1 Olan Bir Derviş: Seyyid Nattâ”, Gümüşlü’den Günümüze Osmanlı Külttüründe Bursa (Bursa: y.y., 2003), 138-148; Murat Sarıcık, Osmanlı İmparatorluğunda Nakîbül-Eşraflık Müessesesi (Ankara: TTK Yayınları, 2003); Murat Sarıcık, "Ebussuûd Efendi'nin Fetvâlarında Seyyidler", Süleyman Demirel Üniversitesi İlahiyat Fakültesi Dergisi, 11 (2004), 63-90; İsmail Hakkı Uzunçarşıll, “Osmanlılar'da Nakîbü'l-Eşraflık”, haz. Ali Dadan, marife, 3 (2004), 431-438; Şit Tufan Buzpınar, "Nakîbüleşraf”, Türkiye Diyanet Vakfi İslâm Ansiklopedisi, (İstanbul: TDV Yayınları 2006), 32/322-324; M. Sadık Akdemir, "Şeriyye Sicillerine Göre XVII. Yüzyılda Isparta'da Nakîbü'l-Eşrâf Kaymakamlığı ve Seyyidler”, Arayışlar, İnsan Bilimleri Araştırmaları 17 (2007), 143-177; Sevgi Ağca, “Osmanlı Devleti'nde Nakîbü'l-Eşrâfllk Müessesesi”, Osmanlı Devleti’nde Ehl-i Beyt Sevgisi (İstanbul: Nefes Yay., 2008), 45-65; Murat Sarıcık, "Nakîbü’l-eşraf Abdülkadir Efendi Tarafından Verilen 1008/1600 Tarihli Siyâdet Hücceti,” EKEV Akademi Dergisi, 35 (2008), 113-126; Mustafa Sabri Küçükaşc1, “Seyyid”, Türkiye Diyanet Vakfi İslâm Ansiklopedisi (İstanbul: TDV Yayınları, 2009), 37/40-43; Mustafa Sabri Küçükaşcl, "Seyyid ve Şerif Kavramlarının Kullanımı", Osmanlı Araştırmaları, 33/33 (2009), 87-129; Saim Yörük, "Adanalı Seyyidler Hakkında Sosyal ve Ekonomik Açıdan Bazı Değerlendirmeler (1701-1750)”, Sosyal Bilimler Araştırma Dergisi, 18 (2011), 1-2; Ayhan Işık, Meşîhat Arşivi Belgeleri Işı̆̆ında Seyyidler ve Nakîbü'l-Eşrâfllk Müessesesi (İstanbul: İstanbul Üniversitesi, Sosyal Bilimler Enstitüsü, Doktora Tezi, 2013); Sevda Tuna, Osmanlı Dönemi Ankara'sinda Sosyo-Ekonomik ve Demografik Açıdan Seyyide ve Şerifeler (M.1786-1835) (Sivas: Cumhuriyet Üniversitesi, Sosyal Bilimler Enstitüsü, Yüksek Li- 
yeterli birikime ulaşıldığı söylenemez. Literatürde gözlenen temel eksiklik, Osmanlı coğrafyasının farklı yer ve zamanlarını konu edinen ve sosyal tarih perspektifiyle hazırlanan çalışmaların azlığıdır. Haddizatında Osmanlı'nın önemli bir toplumsal grubunu teşkil eden seyyidlerin sosyal hayat içerisindeki konumlarına ve ilişkilerine yönelik Osmanlı coğrafyasının farklı yer ve zamanlarını konu edinen çalışmaların, elde edilecek yeni veri ve bulgularla bir bütün olarak Osmanlı sosyal tarihinin aydınlatılmasına katkılar sunacağı aşikârdır.

$\mathrm{Bu}$ araştırma için inceleme bölgesi olarak seçilen Diyarbekir (Âmid) üzerine, seyyidler bağlamında şimdiye kadar yeterli düzeyde araştırma gerçekleștirilmemiştir. ${ }^{25}$ Hâlbuki Diyarbekir, Osmanlı toplumu içerisinde seyyidlerin incelenebileceği sosyolojik olarak en elverişli yerlerdendir. Zira Türkiye sınırları içerisinde gerek bugün gerekse tarihsel olarak Güneydoğu Anadolu, seyyidlerin en yoğun şekilde meskûn oldukları yerler arasındadır. ${ }^{26}$ Nitekim çalışmanın ilerleyen kısımlarında da ortaya konacağı üzere toplumsal rollerine bağlı olarak Osmanlı Diyarbekiri'ndeki seyyidlerin belgelerdeki görünürlükleri bir hayli yüksektir.

\section{Diyarbekir (Âmid) Nakîbüleşrâf Kaymakamlığı}

Sözlükte "vekil, bir topluluğun başkanı" anlamındaki nakîb kelimesiyle Hz. Muhammed'in soyunu ifade eden eşrâftan oluşan terkip, peygamber soyundan gelenlerle ilgilenmek üzere kurulan teşkilâtın sorumlusunu ifade etmektedir. Tarih boyunca Resulullah'ın ailesi, yakın akrabası ve soyundan gelenler müslümanlar nazarında seçkin bir mevkiye sahip olmuş, bunları sayıp sevmenin dinî bir vecibe olduğu

sans Tezi, 2013); Emin Güney, Sivas Tereke Defterlerinden Hareketle Sivas'ta Seyyidlerin Sosyo-Ekonomik Hayatı (1825-1850 Yılları) (İstanbul: Marmara Üniversitesi, Sosyal Bilimler Enstitüsü, Yüksek Lisans Tezi, 2015); Rüya Kılıç, Osmanlıda Seyyidler ve Şerifler (İstanbul: Kitap Yayınevi, 2016); Abdülkadir Özcan, “Osmanlı'da Seyyidler ve Şerifler”, Derin Tarih, Özel Sayı 5 (Mart 2016), 132-136; Ayhan Işık, “Çankırı'nın Manevî Fâtihleri: Çankırı Seyyidleri”, Alevilik Araştırmaları Dergisi, 1 (2017), 77-118; Ercan Gümüş, "Sâdât: 17. ve 18. Yüzyılda Diyarbekir Eyaleti'nde Seyyidler, İmtiyazları ve Sosyo-Ekonomik Konumları Hakkında Bir Değerlendirme”, Sosyal, Beşeri ve İdari Bilimler Alanında Yenilikçi Yaklaşımlar, ed. Kürşat Özdaşlı vd., (Ankara: Gece Akademi Yay., 2018), 3/569-605; Muttalip Şimşek, “Osmanlı Devleti'nde Nakîbüleşraflık Müessesesi ve Bu Müesseseye Bağlı Kaymakamlıklar (19. Yüzyıl), Tarihin Peşinde -Uluslararası Tarih ve Sosyal Araştırmalar Dergisi, 19 (2018), 401-431.

25 17. ve 18. yüzyıl çerçevesinde Diyarbekir Eyaleti'nin geneline yönelik bir çalışma mevcuttur. Ancak bu çalışma konu, yöntem ve kaynaklar açısından bizim araştırmamızdan farklıdır. bk. Ercan Gümüş, “Sâdât: 17. ve 18. Yüzyılda Diyarbekir Eyaleti'nde Seyyidler, İmtiyazları ve Sosyo-Ekonomik Konumları Hakkında Bir Değerlendirme”, Sosyal, Beşeri ve İdari Bilimler Alanında Yenilikçi Yaklaşımlar, ed. Kürşat Özdaşlı vd., (Ankara: Gece Akademi Yay., 2018), 3/569-605.

26 Necat Keskin, Akışkan Kimlikler: Etnik ve Dini Kimlik Arasında Becirman Seyyidleri (Ankara: Hacettepe Üniversitesi, Sosyal Bilimler Enstitüsü, Doktora Tezi, 2014), 97; Adak, “Güneydoğu Anadolu'da Seyyidler”, 366-367. 
kabul edilmiş ve onlarla ilgili bazı hizmetleri ifa etmek üzere görevliler tayin edilmiştir. Böylece zamanla nikâbet kurumu ortaya çıkmış, bununla ilgilenen görevlilere de nakîb, nakîbü'l-eşrâf ve nakîbü'n-nükabâ gibi isimler verilmiștir. ${ }^{27}$ Osmanlı devlet hiyerarşisinde önemli bir yer edinen nakîbüleşrâflar, umumiyetle seyyidler arasından ve ilmiye mensuplarından seçilmiştir. ${ }^{28}$

İstanbul'da ikamet eden Osmanlı nakîbüleşrâfları, diğer şehirlerde seyyidler arasından belli bir süre için nakîbüleşrâf kaymakamları görevlendirirlerdi. Ancak tayinlerde bir derecelendirmeye gidilmişti. Örneğin İstanbul'da bulunan nakîbüleşrâf, Kudüs nakîbüleşrâf kaymakamını, o da Filistin bölgesindeki kaza ve mutasarrıflıkların nakîbüleşrâf kaymakamlarını tayin ederdi. ${ }^{29}$ Ancak incelediğimiz dönemde Diyarbekir nakîbüleşrâf kaymakamlarının doğrudan İstanbul'da bulunan nakîbüleşrâflarca tayin edildiği gözlenmiştir.

Döneme ait şeriyye sicillerinde ve ahkâm defterlerinde Osmanlı Diyarbekiri'ndeki nakîbüleşrâflara dair bazı bilgiler yer almaktadır. Ancak bunlar içerisinde nakîbüleşrâf kaymakamlığına dair elde edilen bilgiler daha ziyade şer'iyye sicillerinde yer alan ve nakîbüleşrâflarca gönderilen tayin belgelerinden elde edilebilmiştir. Bu çerçevede tespit edilen nakîbüleşrâf kaymakamı tayinine dair belge sayısı beş adettir. Bu belgeler, nakîbüleşrâf kaymakamlarının isimlerine, sorumlulukları altındaki kazalara ve bilhassa görev ve yetkilerine dair dikkat çekici bilgiler ihtiva etmektedir. Mezkûr belgelerde tayini gerçekleştirilen kaymakamlara dair bazı bilgiler aşağıdaki tabloda gösterilmiştir. Görev yerlerine bakıldığında 18. yüzyılın ortalarında bir kaymakamın sadece Diyarbekir'in merkez kazası olan Âmid'de vazifeli iken 18. yüzyılın sonlarına doğru görev yerlerinin genişlediği ve değişkenlik arz edebildiği gözlenmektedir.

\begin{tabular}{|l|l|l|l|l|}
\hline $\begin{array}{l}\text { Tayin edilen } \\
\text { Nakíbüleşrâf Kay- } \\
\text { makamı }\end{array}$ & $\begin{array}{l}\text { Görevli olduğu } \\
\text { Kazalar }\end{array}$ & $\begin{array}{l}\text { Tayin Eden } \\
\text { Nakîbüleşrâf }\end{array}$ & Tarih & Belge No \\
\hline $\begin{array}{l}\text { Şeyh Ahmedzâde } \\
\text { es-Seyyid Mehmed } \\
\text { Efendi }\end{array}$ & Âmid kazası & $\begin{array}{l}\text { Seyyid Mehmed } \\
\text { Zeynelabidin el- } \\
\text { Hüseynî }\end{array}$ & $\begin{array}{l}1 \text { Şevvâl 1157 (7 } \\
\text { Kasım 1744) }\end{array}$ & $\begin{array}{l}\text { DŞS, 3775, 10b- } \\
2 .\end{array}$ \\
\hline $\begin{array}{l}\text { Duhânîzâde es-Sey- } \\
\text { yid Ali Efendi }\end{array}$ & $\begin{array}{l}\text { Âmid, Mardin, } \\
\text { Ergani ve Çün- } \\
\text { güş kazaları }\end{array}$ & $\begin{array}{l}\text { el-Fakir es-Seyyid } \\
\text { Mehmed Derviş } \\
\text { Hüseynî }\end{array}$ & $\begin{array}{l}\text { 1 Safer 1200 (4 } \\
\text { Aralık 1785) }\end{array}$ & $\begin{array}{l}\text { DŞS, 3746, 27a- } \\
1 .\end{array}$ \\
\hline
\end{tabular}

27 Ş. Tufan Buzpınar, "Nakîbüleşraf", Türkiye Diyanet Vakfi İslâm Ansiklopedisi, (İstanbul: TDV Yayınları, 2006), 32/322.

28 Buzpınar, "Nakîbüleşraf", 32/323.

29 Buzpinar, "Nakîbüleşraf", 32/323. 


\begin{tabular}{|c|c|c|c|c|}
\hline $\begin{array}{l}\text { Kapânîzâde es-Sey- } \\
\text { yid Asım Efendi }\end{array}$ & $\begin{array}{l}\text { Âmid, Mardin, } \\
\text { Ergani ve Çün- } \\
\text { güş kazaları }\end{array}$ & $\begin{array}{l}\text { el-Fakir es-Seyyid } \\
\text { Mehmed Derviş } \\
\text { el-Hüseynî }\end{array}$ & $\begin{array}{l}1 \text { Cemaziyelula } \\
1200 \text { (2 Mart 1786) }\end{array}$ & $\begin{array}{l}\text { DŞS, 3746, 31b- } \\
1 .\end{array}$ \\
\hline $\begin{array}{l}\text { el-Hâc Mehmed } \\
\text { Nazif Efendi }\end{array}$ & $\begin{array}{l}\text { Âmid, Ergani, } \\
\text { Çüngüş, Sive- } \\
\text { rek ve Çermik } \\
\text { kazaları }\end{array}$ & $\begin{array}{l}\text { Mehmed Siddık } \\
\text { el-Hüseynî }\end{array}$ & $\begin{array}{l}1 \text { Şa'bân } 1238 \text { (13 } \\
\text { Nisan 1823) }\end{array}$ & DŞS, $3745,8 b-1$. \\
\hline $\begin{array}{l}\text { Şeyhzâde es-Seyyid } \\
\text { Mustafa Ağa }\end{array}$ & $\begin{array}{l}\text { Âmid, Ergani, } \\
\text { Çüngüş ve Sive- } \\
\text { rek kazaları }\end{array}$ & $\begin{array}{l}\text { el-Fakir Selim } \\
\text { Mollâzâde Abdür- } \\
\text { rahim el-Hüseynî }\end{array}$ & $\begin{array}{l}1 \text { Rebî́ülevvel } \\
1256 \text { (3 Mayıs } \\
\text { 1840) }\end{array}$ & $\begin{array}{l}\text { DŞS, 3804, 10b- } \\
2 .\end{array}$ \\
\hline
\end{tabular}

Nakîbüleşrâf kaymakamlarının tayinlerine dair belgelerde tanımlanan görev ve yetkiler ile devletin seyyidlere ne denli önem atfettiği açık biçimde gözlenmektedir. Söz konusu belgelerde görev ve yetkiler ifade edilirken bazı hususlara dair uyarıların yapıldığı da dikkat çekmektedir. Bu uyarılar, bilhassa ilgili dönemde yaşanılan bazı problemlere işaret etmesi bakımından önem arz etmektedir. Mevzuya dair belgelerdeki muhteva birbirine oldukça yakındır ve aynı minvaldedir. Dolayısıyla bu belgelerden birinin örnek sadedinde zikredilmesiyle iktifa edilecektir.

1 Safer 1200 (4 Aralık 1785) tarihli belgede ${ }^{30}$ Âmid, Mardin, Ergani ve Çüngüş kazalarındaki seyyidler üzerine nakîbüleşrâf kaymakamı tayin edilen Duhânîzâde esSeyyid Ali Efendi'nin "sâdât-1 kirâma" saygı ve hürmette kusur göstermemesi ilk dile getirilen ve talep edilen husustur. Kendisinden, kadılar veya nakîbüleşrâf kaymakamlarından seyyidlik belgesi temin edenlere firsat vermemesi, seyyidlik iddiasında bulunanların nakîbüleşrâflığa yönlendirilmesi istenmiştir. Bu noktada kadılar veya nakîbüleşrâf kaymakamlarından temin edilen seyyidlik belgelerinin kabul edilmeyeceğinin vurgulanması da dikkate değerdir. Bu uyarı, ilgili dönemde bu minvalde temin edilen belgelerin güvenilirliklerinin sorunlu olduğuna ve devletin bu konuda sorun yaşadığına işaret etmektedir. Nitekim Osmanlı genelinde de rüşvet veya sahte evrak ile seyyidlik belgesinin tanzim ettirilebildiği bilinmektedir. ${ }^{31}$ Dolayısıyla devlet, bu probleme mâni olmak amacıyla seyyidlik iddiasında bulunanların İstanbul'da bulunan nakîbüleşrâflığa müracaat etmesini sağlamakta ve gerekli belgeyi burada tanzim ettirmektedir.

Mezkûr belgeye göre nakîbüleşrâf kaymakamının, seyyidliği sabit olmayan kimselerin "alâmet-i hadrâ" yani seyyidlik alameti olan yeşil rengi kullanmalarına mâni olması gerekmektedir. Bunun yanı sıra görev ve yetki sahası içerisindeki seyyidlerin

\footnotetext{
30 DŞS, 3746, 27a-1.

31 Kılıç, Osmanlıda Seyyidler ve Şerifler, 64.
} 
yargılama sonrası ceza ve tedibi gerektirecek bir durumları hâsıl olursa bunu kendisinin yapması, onları diğer devlet görevlilerine rencide ettirmemesi istenmektedir. Nitekim ilgili dönemde bu minvalde yaşanan bazı sorunların sicillere yansıdığı da gözlenmektedir. Öyle ki nakîbüleşrâf kaymakamları bir yandan usulsüz biçimde seyyidlik iddiasında bulunanlarla mücadele etmek durumundayken bir diğer yandan seyyidlere yönelik hukuksuz eylemleri engellemekle uğraşmışlardır. İlerleyen kısımlarda bu hususlara ayrıca temas edilecektir.

Nakîbüleşrâf kaymakamlarının tayin belgelerinde icra edecekleri bu görev, "emânet-i kübrâ", yani büyük emanet olarak tanımlanmıştır. ${ }^{32}$ Onlardan bu görev süresince, "kemâl-i iffet" ile tevcihiye, arûsiye veya başka herhangi bir ad ile seyyidlerden herhangi bir şey talep etmemeleri, onların mal ve namuslarının elden geldiğince korunmasına ihtimam gösterilmesi istenmiştir. ${ }^{33}$ Bu surette "Padişah-1 İslam'ın devâm-1 ömr-i devletleri" için seyyidlerin hayır dualarının alınması talep edilmiştir. ${ }^{34}$ Onların hayır dualarına özel bir değer atfedilmesi, seyyid dualarının Allah katında daha makbul olduğuna inanıldığını ve onların diğer insanlardan ve Müslümanlardan daha üstün görüldüğünü ihsas etmektedir. Bu değerlendirmeyi destekleyen başka bulgular da mevcuttur ve bunlara ilerleyen kısımlarda temas edilecektir.

Belgelerin son kısmında bu ulvi görevi icra eden kaymakamların her işlerinde $\mathrm{Hz}$. Peygamber'i örnek alarak hareket etmelerinin istenmesi de dikkat çekmektedir. ${ }^{35} \mathrm{Bu}$ son vurgu, nakîbüleşrâf kaymakamlığının sıradan bir memuriyet makamı olarak görülmeyerek manevi boyutunun ön planda yer aldığını göstermektedir. Zira ilgilenilecek kişilerin Hz. Peygamber'in soyundan olmaları önem arz ettiği gibi kaymakamların kendileri de bu soydandırlar. Binaenaleyh bu manevi sorumluluğa muvafık davranmaları kendilerinden beklenmektedir.

Zikrolunan belgelerdeki görev ve yetkilerin uygulamaya nasıl yansıdığı döneme ait bazı sicillerde gözlenebilmektedir. Bu vakalar seyyidlik iddialarına ve bunların ispatına yönelik dikkate değer görünümler sunmaktadır. Örneğin 1233 (1818) yılına ait bir belgede Diyarbekir Nakîbüleşrâf Kaymakamı Seyyid Ömer Efendi, mahkemeye müracaat ederek Şeyhmus b. Seyyid Mirza'nın reayadan olmasına rağmen kanuna aykırı olarak yeşil sarık kullandığını iddia ederek kendisinden davacı olmuştur. Davalı "âbâ û ecdadının sâdâttan" olduğunu ve hepsinin yeşil sarık kullandığını iddia etmişse de mezkûr kaymakam bu iddiayı reddetmiştir. Davalıdan iddiasını ispat edecek delil talep edilince çok sayıda kişi iddianın doğruluğuna yönelik mahkeme huzurunda tanıklıkta bulunmuş ve kadı davalıyı haklı bularak nakîbüleşrâf kaymakamını

\footnotetext{
32 DŞS, 3746, 27a-1; DŞS, 3746, 31b-1; DŞS, 8b-1; DŞS, 3746, 10b-2; DŞS, 3746, 10b-2.

33 DŞS, 3746, 27a-1; DŞS, 3746, 31b-1; DŞS, 3745, 8b-1; DŞS, 3808, 10b-2.

34 DŞS, 3746, 27a-1; DŞS, 3746, 31b-1.

35 DŞS, 3746, 27a-1; DŞS, 3746, 31b-1; DŞS, 3745, 8b-1; DŞS, 3808, 10b-2; DŞS, 3775, 10b-2.
} 
muarazadan men etmiştir. ${ }^{36}$ Dolayısıyla bu vaka, nakîbüleşrâf kaymakamının seyyidliğinden şüphe duyduğu bir kimseyi mahkemeye çıkarabildiğini, ancak mahkemeye çıkarılan kişinin, seyyidliğini ispatlayabilirse seyyidlik alametini kullanmaktan men edilemediğini göstermektedir.

$\mathrm{Bu}$ dönemde nakîbüleşrâf kaymakamlarının görevden alındıkları da olmuştur. $\mathrm{Bu}$ uygulama döneme ait bir belgeye “...Küçük Ahmedzâde Mehmed İzzet Efendi'nin ol hizmet-i celîleden hacrı lazım geldiğine..." ifadesiyle yansımıştır. Ancak mezkûr belgede görevden alınma sebebinin ne olduğu belirtilmemiştir. ${ }^{37}$

Diyarbekir ahkâm defterlerine yansıyan bir fermanda, ehl-i örf'ten bazı kimselerin seyyidlere hukuka aykırı biçimde müdahalede bulunabildikleri ve dolayısıyla nakîbüleşrâf kaymakamlarının görev ve yetki sahasını ihlal edebildikleri anlaşılmaktadır. Evâhir-i Cemâziyelevvel 1234 (18-27 Mart 1819) tarihli bu belge ile seyyidlerin hukuka aykırı bir eylemleri vuku bulduğunda veya iddia edildiğinde takip edilmesi gereken prosedürün ne şekilde olması gerektiği de ifade edilmektedir. Mezkûr belgeye göre Diyarbekir'de nakîbüleşrâf kaymakamı olan es-Seyyid eş-Şeyh Mustafa, Dîvân-1 Hümâyûn'a müracaat ederek ehl-i örften olup hukuksuzlukta bulunan bazı kimseleri şikâyet ederek bunun engellenmesini talep etmiştir. Mezkûr belgede şikâyet konusu olan hukuksuzluk şu şekilde ifade edilmektedir:

“...kazâ-i mezbûrda sâkin sahîhu'n-neseb sâdât-1 kirâmdan olanların içlerinde birinden bir kimesnenin hukûka müte'allik da'vâ-yı şer'iyyesi vukûtunda meclis-i şer'i şerîfe ihzârı ve ahz u habs ve te'dîbi ve hukûk-1 şer'iyye tahsîl lâzım geldikde kânûn1 kadîm üzere zâbitleri olan nakîbüleşrâf kâimmakâmı mûmâileyh ma'rifetiyle rü'yet olunup ehl-i örf tâifesi câniblerinden ta'addî olunmak îcâb etmez iken bu esnâda ehli örf tâifesi taraflarından hilâf-1 kânûn ve kadîme mugâyir ahz u habs teklîfiyle ta'addî olunduğun bildirip..." 38

Söz konusu belge içeriğinde seyyidlerden herhangi bir kimsenin davalık bir durumu söz konusu olduğunda onların da şerî̀ mahkeme huzuruna çıartılarak yarg1lanmaları gerektiği ifade edilmiştir. Dolayısıyla bu hususta onlarla diğer reaya arasinda herhangi bir fark yoktur. Ancak bu süreçte mahkemeye getirilme, tutuklanma, hapis, tedib veya icrası lazım gelen herhangi bir şerî hüküm söz konusu olduğunda bunu icra etme vazife ve yetkisinin nakîbüleşrâf kaymakamlarında olduğu belirtilmektedir. Yarg1 ve tenfiz sürecinde ehl-i örften kimselerin seyyidlere müdahale etmesine mâni olunmak istenmesi, daha önce de ifade edilen, seyyidlere duyulan üstün hürmetten kaynaklanmaktadır. Yukarıda da belirtildiği üzere nakîbüleşrâf kaymakamlarının görevlerinin başında seyyidlerin "rencide" edilmesine mâni olmak gelmektedir. Dolayısıyla ilgili dönemde ehl-i örften bazı kimselerin seyyidlere yönelik böylesi hukuksuzluklarda bulunabildikleri anlaşılmaktadır. Ancak bu çok nadirdir.

\footnotetext{
36 DŞS, 3787, 17b-2.

37 DŞS, 3745, 8b-1.

38 DŞS, 3754, 36b-2.
} 
Zira bu hususta sıklıkla karşılaşılan bir ihlal söz konusu olsaydı, eldeki belgeler arasında kaymakamların çok daha fazla şikâyet kaydına rastlanması gerekirdi. Anlaşılan odur ki Dîvân-1 Hümâyûn, nakîbüleşrâf kaymakamının arkasında durarak seyyidlerin hukukunu korumaya gayret etmiştir. Nitekim ilgili fermanda adı geçen nakîbüleşrâf kaymakamının şikâyeti haklı bulunarak Diyarbekir kazası nâibine gerekli kanunun uygulanarak hukuksuzluğun giderilmesi talimatı verilmiştir. ${ }^{39}$

\section{Seyyidlerin Ailevi İlişkileri}

Döneme ait belgeler içerisinde Diyarbekir'deki seyyidlerin aile hayatlarına $1 s ̧ 1 k$ tutan bazı bilgi ve bulgulara da ulaşılmıştır. Bu hususta bilhassa tereke kayıtlarının faydalı olduğu belirtilebilir. Döneme ait belgeler içerisinde 18 seyyid ve bir seyyideye ait tereke kaydı tespit edilmiştir. Öncelikle şu ifade edilebilir ki ortaya çıkan bu terekeler, varislerin müracaatı halinde seyyid ve seyyidelerin terekelerinin de toplumun diğer kesimlerini oluşturan halkın terekeleriyle aynı muameleye tabi tutulduğunu göstermektedir. Ancak incelenen dönemin genişliği ve diğer kesimlere ait terekelerin yoğunluğu göz önünde tutulduğunda anlaşılan odur ki seyyid ve seyyidelere ait terekeler genelde şer'î mahkemeye taşınmamış, bu durum istisnai hâllerde veya ihtiyaç hâsıl olduğunda vaki olmuştur. Bir diğer ifadeyle seyyidler terekelerini mahkemeye yansıtmadan kendi aralarında gerekli miras taksimatına tabi tutmuşlardır. Bu taksimatlarda varisler arasında pek sorun yaşanmadığı anlaşılmaktadır. Zira aksi hâlde tarafların çekişmesinden ötürü mahkemeye intikal eden birtakım miras davalarının olması beklenirdi.

Mezkûr tereke kayıtlarının 11'inde eşlerin isimleri zikredilmiştir. Bu belgelerde verilen bilgilere göre seyyidler büyük oranda tek eşlidirler. Sadece bir seyyidin iki hanımının bulunduğu tespit edilmiştir. ${ }^{40}$ Yine dikkati celbeden bir diğer husus da eyalet valisi konumunda olan bir seyyidin terekesinde yer alan bir ümm-i veled cariye $^{41}$ hariç- terekelerdeki mallar arasında herhangi bir köle veya cariyenin yer almamasıdır. Konuya dair tereke kayıtlarının dışındaki belgelere bakıldığında da benzer bir tabloyla karşılaşılmaktadır. Buralarda da sadece bir belgede bir başkasıyla ortak olarak -muhtemelen ticari bir amaçla- cariye satın alma işleminde bulunan bir seyyide rastlanmıştır. ${ }^{42}$ Bunun haricinde köle veya cariye sahibi olan seyyid veya seyyidelere rastlanmamıştır. Hâlbuki döneme ait belgelerde birçok kişinin köle ve bilhassa cariye sahibi olduğu gözlenmiştir. Bu da ilgili dönemde seyyid veya seyyidelerin köle istihdam etmeye ve cariye edinmeye sıcak bakmadıklarına dair önemli bir görünümdür. Kur'an-i Kerim Müslümanları köle ve cariyeleri azat etmeye, onları hürriyetlerine kavuşturmaya teşvik etmektedir. Hz. Peygamber de eline geçen köle

\footnotetext{
39 DŞS, 3754, 36b-2.

40 DŞS, 3714, 10b-1.

41 DŞS, 3680, 72b-1.

42 DŞS, 3775, 23b-1.
} 
ve cariyeleri azat etmiş ve buna teşvikte bulunmuştur. Binaenaleyh İslam hukukunun köleliğe yaklaşımı da bu yönde şekillenmiştir. ${ }^{43}$ Bu noktada seyyid ve seyyidelerin köleliğe karşı tutumunun İslam'ın gayesine muvafık bir tavır olduğu söylenebilir. İlgili dönemde Osmanlı Diyarbekiri'ndeki mollaların da benzer bir tutum içerisinde olmaları dikkat çekicidir. ${ }^{44}$

Tereke kayıtlarında seyyid hanımı olan 12 kadının ismi zikredilmiştir. Ancak bunların isimlerinin önünde seyyidlerden olduklarına dair herhangi bir unvan bulunmamaktadır. Ancak bu noktada ilgili hanımların seyyidlerden olmadıkları veya seyyidlerin evlilik için seyyideleri tercih etmedikleri yönünde bir genellemede bulunmanın isabetli olmayacağı belirtilmelidir. Zira ilgili belgeler seyyid ailelerinden gelmelerine rağmen bu dönemde kadınlar için seyyidelik veya şerifelik unvanının neredeyse hiç kullanılmadığını ortaya koymaktadır. ${ }^{45}$ Zira sadece bir belgede şerife unvanına rastlanmıştır. ${ }^{46}$ Bunun yanı sıra kadınların baba isimlerinin önünde seyyid unvanının kullanılmamış olması da mezkûr kişilerin kesin biçimde seyyide/şerife olmadığını göstermez. Zira birçok belgede babanın seyyid olmasına rağmen bu unvanın kullanılmadığı anlaşılmaktadır. ${ }^{47}$

Sözü edilen terekelerin 12'sinde seyyid ve seyyidelerin çocuk sayılarına dair de bilgi edinilebilmektedir. 10 çocuğuyla istisnai bir durum arz eden eyalet valisi ${ }^{48} \mathrm{kap}-$ sam dişı bırakılırsa 11 seyyid ${ }^{49}$ ve seyyidenin ${ }^{50}$ çocuk sayılarının aritmetik ortalamasının 3.27 olduğu görülür. Bu da seyyid ve seyyidelerin çocuk sayılarının genel itibariyle orta düzeyde olduğuna işaret etmektedir. Söz konusu evlatlara dair bir diğer dikkat çekici görünüm de isimlerinde sıklıkla erkekler için Hasan, Hüseyin, Mehmet, Mahmut, Mustafa ve Ali; kadınlar için de Hatice, Aişe, Rukiye, Fatma ve Zeynep gibi Hz. Peygamber'in ve onun ehl-i beytinin isimlerinin tercih edilmiş olmasıdır.

Yukarıda da temas edildiği gibi ilgili belgeler, bazı kişilerin seyyid ve seyyide olmalarına rağmen bu unvanların her zaman zikredilmeye gerek duyulmadığını göstermektedir. Dolayısıyla seyyid ve seyyidelerin evli oldukları kişilerin kendileriyle aynı zümreden olup olmadığını kesin biçimde ayırabilmek mümkün değildir. Ancak

${ }^{43}$ Mehmet Âkif Aydın-Muhammed Hamîdullah, "Köle”, Türkiye Diyanet Vakfi İslâm Ansiklopedisi, (Ankara: TDV Yayınları, 2002), 26/241-243.

44 Ümit Güler, “Osmanlı Sosyal Hayatında Mollalar: 18. ve 19. yy. Diyarbekir Örneği”, e-Şarkiyat İlmi Araştırmalar Dergisi, 11/2 (Ağustos 2019), 866.

45 Örnekler için bk. "Hamide bt. es-Seyyid Süleyman” bk. DŞS, 3714, 9b-3; "Emine bt. es-Seyyid Mehmed" bk. DŞS, 3714, 31b-3; ayrıca bk. DŞS, 3718, 29a-1; DŞS, 3746, 4a-1; DŞS, 3714, 1b-2; DŞS, 3714, 10b-1; DŞS, $3680,72 b-1$.

46 Diyarbekir Ahkâm Defterleri (DAD), 5, 102-1.

47 DŞS, 3680, 112b-1; DŞS, 3745, 20b-2; DŞS, 3680, 11b-1; DŞS, 3775, 20 b-2.

48 DŞS, 3680, 72b-1.

49 DŞS, 3746, 2b-2; DŞS, 3742, 2b-2; DŞS, 3742, 25b-2; DŞS, 3742, 40b-1; DŞS, 3742, 45b-1; DŞS, 3714, 1b-2; DŞS, 3714, 10b-1; DŞS, 3714, 11b-2; DŞS, 3714, 13b-1; DŞS, 3714, 18a-3.

50 DŞS, 3714, 17b-1. 
belgelerin genelinden elde edilen izlenim seyyid ve seyyidelerin eş seçiminde kendi zümreleriyle sınırlanmış olmadıkları yönündedir. Bu durum erkeklerde daha belirgin olmakla birlikte kadınların da zümrelerinin dışındaki kişilerle evlendiklerini gösteren örneklere rastlanmıştır. ${ }^{51} \mathrm{Bu}$ da zümrenin içinden ve dışından kişilerle evliliklerin gerçekleștiğine ve dolayısıyla seyyid ve seyyidelerin toplumun diğer kesimlerine kapalı bir sosyal grup olmadığına işaret etmektedir.

Sicil defterleri genel itibariyle boşama ve boşama sonrası mehir, nafaka veya hul koşulları gibi hususlarda taraflar arasında meydana gelen ihtilaflara dair oldukça bol biçimde kayıt ihtiva ederler. Bu durum Diyarbekir sicilleri için de geçerlidir. Ancak bu hususlarda dikkat çekici bir biçimde seyyidlere dair kayıt sayısı son derece azdır. Bunun yanı sıra aile içi cürüm veya şikâyet hadiselerine de rastlanmış değildir. Bu da seyyid ailelerinin umuma nispetle daha sağlıklı bir yapıda olduklarına ve İslam dinince "en çirkin helal" olarak vasıflandııılan boșama/boşanma uygulamasından kaçındıklarına işaret etmektedir. Ancak bu durum seyyidlerin hiçbir zaman hanımlarını boşamadıkları gibi bir anlama da gelmemektedir. Zira kimi belgeler oldukça nadir de olsa boşamaların vaki olabildiğini göstermiștir. ${ }^{52} \mathrm{Hatta}$ bu kapsamda zikredilebilecek bir örnek oldukça ilginçtir. 4 Zilka'de 1136 (25 Temmuz 1724) tarihli belgeye göre Dağ Kapısı haricindeki Arablar köyünden Hüsna bt. İbrahim adlı kadın mahkemeye müracaat ederek eski eşi Seyyid Mustafa b. el-Hâc Mustafa'nın altı ay önce talak-1 selâse ile kendisini boşadığını, bunun akabinde Kozan b. Asaf adlı kişiyle evlendiğini bu şahsın da 97 gün önce talak-ı selâse ile kendisini boşadığını beyan ederek tekrar ilk eşiyle evlenmesine herhangi bir mâni olup olmadığını sormuş ve mahkeme de konuya dair verilen muteber bir fetvaya istinaden mezkûr eski kocası ile tekrar evlenmesinde herhangi bir mâninin bulunmadığını belirtmiștir. ${ }^{53}$

\section{Seyyidlerin Meslekleri, Toplumsal Rol ve Statüleri}

Döneme ait şer 'iyye sicillerinde yer alan seyyidlerin birçoğunun isminde mesleki durumlarını ifade eden unvanlar tespit edilmiştir. Bunlar sayesinde ilgili dönem Diyarbekir'inde seyyidlerin hangi meslekleri icra ettiklerine, toplum içerisindeki konum ve rollerine dair dikkate değer bilgiler elde edilebilmektedir. Aşağıda yer alan tabloda da gözlemlenebileceği gibi Osmanlı Diyarbekiri'nde seyyidlerin eyalet valiliği gibi taşra teşkilâtında en büyük idarî birim olan eyaletin askeri ve idari âmirliğini ifa eden altı seyyid tespit edilmiştir. Bunun yanı sıra kadılık veya kadı nâibliği görevini icra eden 14 seyyid bulunmaktadır. Şüphesiz valilik görevinden sonra en mühim makamların başında kadılık gelmektedir. Zira mülki, beledi, mali, askeri ve adli sahaları kapsayan görevleri itibariyle Osmanlı devlet teşkilatında onun kadar geniş bir görev alanı bulunan bir başka memur bulunmamaktadır. Kadılar, şer'î hukuku tatbik etmekle birlikte mülki erkân içinde yer alırlar ve aynı zamanda reayanın da merkezi

\footnotetext{
51 DŞS, 3714, 9b-3; DŞS, 3714, 31b-3.

52 DŞS, 3746, 4a-1.

53 DŞS, 3746, 4a-1.
} 
devlet karşısında temsilcisi ve sözcüsü konumundadırlar. ${ }^{54}$ Dolayısıyla seyyidlerin valilik veya kadı ve kadı nâibliği makamında bulunmaları devlet tarafından onlara atfedilen değeri gösterdiği gibi Osmanlı Diyarbekiri'ndeki saygınlıkları açısından da olumlu bir etki oluşturduğu aşikârdır.

Seyyidlerin gözlendiği bir diğer önemli vazife sahası da müderrislik, vakıf mütevelliliği, müftülük, imam, hatip ve müezzinlik gibi dinî veya dinî misyonu olan hizmetlerdir. Bilhassa vakıf mütevelliliği ve vakıfların bünyesindeki diğer görev alanlarında seyyidlerin etkili oldukları anlaşılmaktadır. Osmanlı'da vakıfların ve vakıflarla ilgili görevlerin manevi bir boyutunun ve sorumluluğunun olduğu, bu gibi görevleri saygın ve güvenilir kişilerin ifa ettiği bilinmektedir. ${ }^{55}$ Dolayısıyla bu vazifeler için seyyidlerin uygun görülmesi onların toplum nezdinde tesis ettikleri saygı ve güvene işaret etmektedir. Ayrıca sözü edilen görevlerin icrasında seyyidler aleyhine herhangi bir suç veya şikâyetin mahkeme kayıtlarına yansımamış olduğu da ifade edilebilir. Bu da onların ehliyet ve güvenilirliklerine dair olumlu nitelikte bir bulgudur.

Aşağıdaki tabloda da gözlenebileceği üzere Osmanlı Diyarbekiri'nde seyyidlerin din hizmetleri bașta olmak üzere yargı hizmetlerinde, idari görevlerde ve esnaflık sahasında yoğun olarak varlık gösterdikleri anlaşılmaktadır. ${ }^{56}$ Bunların haricinde sipahilik, silahşörlük gibi askeri hizmetlerde nadiren görev aldıkları gözlenmiştir. Ancak payitahttaki bazı kritik vazifelere Diyarbekir seyyidlerinden tayin yapıldığı olmuștur. Örneğin 1238 (1823) tarihli bir belgede Diyarbekir ileri gelenlerinden Serzağarî Seyyid Mustafa Ağa'nın Dergâh-1 Âli Kapıcıbaşıllı̆ına tayin edildiği ifade edilmiştir. $^{57}$

Tablo 1:

\begin{tabular}{|l|l|l|l|l|l|}
\hline \multicolumn{5}{|c|}{ İlgili Şer'iyye Sicillerinde Yer Alan Seyyidlerin Mesleklerine Göre Dağılımı } \\
\hline Meslek & Sayı & Meslek & Sayı & Meslek & Sayı \\
\hline Kadı ve Nâib & 14 & Muhzırbaşı & 2 & Çeri Başı & 1 \\
\hline Müderris & 8 & Münâdî & 2 & Emir Ağası & 1 \\
\hline
\end{tabular}

54 İlber Ortaylı, "Kadı", Türkiye Diyanet Vakfi İslâm Ansiklopedisi (İstanbul: TDV Yayınları, 2001), 24/69-70; Geniş bilgi için bk. İlber Ortaylı, Hukuk ve İdare Adamı Olarak Osmanlı Devleti’nde Kadı (İstanbul: Kronik Yay., 2016), $40 \mathrm{vd}$.

55 Nazif Öztürk, "Mütevelli”, Türkiye Diyanet Vakfi İslâm Ansiklopedisi (İstanbul: TDV Yayınları, 2006), $32 / 219$.

56 Benzer bir tespit için bk. Gümüş, "Sâdât: 17. ve 18. Yüzyılda Diyarbekir Eyaleti'nde Seyyidler, İmtiyazları ve Sosyo-Ekonomik Konumları Hakkında Bir Değerlendirme”, 3/584, 590.

57 DŞS, 3745, 15a-1. 


\begin{tabular}{|c|c|c|c|c|c|}
\hline Mütevelli & 7 & Tercüman & 2 & Nöbetçi & 1 \\
\hline Vali & 6 & Penbeci & 1 & Mütesellim & 1 \\
\hline Müftü & 4 & Keçeci & 1 & Voyvoda & 1 \\
\hline Nâzır-1 Vakf & 4 & Mimar & 1 & Ekmekçi Şeyhi & 1 \\
\hline İmam & 4 & Kayyum & 1 & Mukayyid & 1 \\
\hline Kasap & 4 & Vakıf Mutasarrifi & 1 & Muallim-i Mektep & 1 \\
\hline Kelekçi & 3 & Muhâsip & 1 & Helvacı & 1 \\
\hline Haffâf & 3 & Müezzin & 1 & Pazarcıbaşı & 1 \\
\hline Başkâtip & 2 & Sermahfil & 1 & Barutçu & 1 \\
\hline Kâtip & 2 & Silahşorân-1 Hassa & 1 & Eskici & 1 \\
\hline Hatip & 2 & Sipahi & 1 & Debbâğ & 1 \\
\hline Kahveci & 2 & Sürgücü Beyi & 1 & Hatabc1 & 1 \\
\hline Sabuncu & 2 & Bezzâz & 1 & Tavukçu & 1 \\
\hline Şişeci & 2 & Şeyh & 1 & Kilerci & 1 \\
\hline Katırc1 & 2 & Tatar Ağas1 & 1 & Neccâr & 1 \\
\hline Kavukçu & 2 & Şehremini & 1 & & \\
\hline Defterdâr & 2 & Câbi Vekili & 1 & & \\
\hline Bevvâb ve Ferrâş & 2 & $\begin{array}{l}\text { Dergâh-1 Âli Kap1- } \\
\text { cıbaşılığ1 }\end{array}$ & 1 & Toplam & 117 \\
\hline
\end{tabular}

Seyyidlerin isimlerinde yer alan mesleki unvanlar yukarıda beyan edildiği gibi ilgili dönemdeki seyyidlerin iştigal ettikleri mesleklere dair kıymetli bilgiler sunmuştur. Ancak seyyidlerin isimlerinde yer alan bazı unvan ve lakaplar vardır ki bunlar muayyen bir mesleğe ait olmamakla beraber kişinin toplumsal rol ve statüsüne 1şık 
tutabilmektedir. Dolayısıyla bu kapsamdaki verilerin analiz edilmesi Osmanlı Diyarbekiri'ndeki seyyidlerin sosyal hayatlarının aydınlatılmasına katkı sunacaktır. Bu kapsamda olduğu tespit edilen unvan ve lakaplar efendi, el-hâc, ağa, halîfe, molla, mevlânâ ve hâfiz olup bunların sayı ve oranları aşağıdaki tabloda gösterilmiştir.

Tablo 2:

\begin{tabular}{|l|l|l|}
\hline Efendi & 52 & $\% 40.94$ \\
\hline el-Hâc & 20 & $\% 15.74$ \\
\hline Ağa & 20 & $\% 15.74$ \\
\hline Halîfe & 12 & $\% 9.44$ \\
\hline Molla & 8 & $\% 6.29$ \\
\hline Mevlânâ & 8 & $\% 6.29$ \\
\hline Hâfız & 7 & $\% 5.51$ \\
\hline Toplam & 127 & \\
\hline
\end{tabular}

Tabloda da gözlenebileceği üzere bu kapsamda olduğu tespit edilen 127 unvanın \%40.94 (52 kişi) ile oransal açıdan en büyük kısmını efendi unvanı teşkil etmektedir. Dolayısıyla Osmanlı Diyarbekiri'nde seyyidler için en yaygın kullanılan unvanın efendi olduğu anlaşılmaktadır. Osmanlı Devleti'nde bu unvanın, XV. yüzyılın ikinci yarısından itibaren tahsilli, itibarlı ve saygıdeğer kimselere mahsus bir tabir olarak kullanılmaya başlandı̆̆ı; sosyal, siyasi, ilmi, dinî ve tasavvufi çevrelerde giderek geniş bir kullanım alanı bulduğu ifade edilir. ${ }^{58}$ Dolayısıyla bu unvan muayyen bir mesleğe işaret etmese de kişinin itibarlı, tahsilli ve saygıdeğer bir konumda bulunduğunu göstermektedir.

Efendiden sonra seyyidlerin isimlerinde bulunan en yaygin tabirlerin ikincisi de \%15.74'lük oranla el-hâc lakabıdır. 20 seyyidin isminde rastlanan el-hâc ibaresi, bu kişilerin hacı olduklarını göstermektedir. Osmanlı toplumunda hacı olan kişilere saygı duyulmakta ve özel bir değer atfedilmektedir. ${ }^{59}$ İslam hukuk teorisi açısından kişinin

58 Orhan F. Köprülü “Efendi”, Türkiye Diyanet Vakfi İslâm Ansiklopedisi (İstanbul: TDV Yayınları, 1994), 10/455-456.

59 Nevzat Erkan, “Siciller Işı̆̆ında Meşakkatli Bir İbadet Olan Hac ve Osmanlı Hacıları”, Manisa Celal Bayar Üniversitesi Sosyal Bilimler Dergisi, 3, (2019), 446. 
hac ibadetiyle mükellef olabilmesi için belirli bir düzeyde mali imkânı bulunmalıdır. ${ }^{60}$ Nitekim ilgili dönemde Osmanlı toplumunda da bir kimsenin hacı olabilmesi için dikkate değer bir maddi güce sahip olması gerektiği bilinmektedir. ${ }^{61}$ Dolayısıyla hacı olan seyyidlerin genel itibariyle maddi olanaklarının iyi bir düzeyde olduğu ve toplum tarafindan saygı gördüğü düşünülebilir.

el-Hâc lakabında olduğu gibi \%15.74'lük bir orana tekabül eden 20 seyyidin isminde ağa unvanı tespit edilmiştir. Osmanlı devlet teşkilatının genişleme ve gelişmesi ile birlikte ağa, askeri teşkilatta en çok kullanılan unvan haline gelmiştir. Oldukça geniş bir kullanım alanı olan bu unvanı, eyalet ve sancakların askeri valileri olan paşa ve beylerden sonra imparatorluğun askeri teşkilatındaki bütün âmirler, saray teşkilatındaki kuruluşların başında bulunanlar ve hatta bazı mülki reisler taşımışlardır. Bunun yanı sıra uzun ve mağlubiyetle sona eren harpler sonrasında Osmanlı idaresinin, Anadolu'da gittikçe zayıf bir hâl aldığı ve bunun neticesinde köylerin, yörelerin ve hatta bazı bölgelerin idaresinin oralardaki kuvvetli aile ve şahısların eline geçtiği belirtilmektedir. Bu süreçte ortaya çıan ve âyan adı verilen kişiler iktidarlarına ve dayandıkları kuvvete göre, bir veya birçok köyü, yöreleri ve bölgeleri idare edebilmiş ve bunların pek çoğu ağa unvanını taşımışlardır. ${ }^{62}$ Dolayısıyla bu unvanı taşıyan seyyidlerin muayyen olarak hangi mesleği icra ettikleri tam olarak bilinemese de toplumsal statülerinin yüksek olduğu söylenebilir.

İlgili dönem seyyid isimlerinde rastlanan bir başka lakap da haliffedir. Bu kapsamda 12 kişi tespit edilmiştir ve bu, oran itibariyle \%9.44'e tekabül etmektedir. Halîfe tabirinin birçok makam için kullanıldığı söylenebilir. Örneğin Hz. Peygamber'in vefatı akabinde devlet idaresini devralan kişilere halîfe dendiği gibi, devlet dairelerindeki yazı işlerinde çalışanlar için de kullanılan bir tabirdir. ${ }^{63}$ Halîfe, tarikatlarda şeyhi adına irşat faaliyetinde bulunan ve ölümünden sonra yerine geçen kimseyi ve insan-1 kâmili de ifade eden bir tasavvuf terimidir. ${ }^{64}$ Bunların haricinde Osmanlı'da bulundukları mesleki konumda vekil veya muavin olarak yer alan kişilere de halîfe dendiği belirtilmektedir. ${ }^{65}$ Ilgili seyyidlerin isimlerinde rastlanan halîfe lakaplarının da bu son anlamda kullanıldığı, yani bulundukları meslekte yardımcılık veya vekillik yaptıkları anlaşılmaktadır.

60 Salim Öğüt, "Hac”, Türkiye Diyanet Vakfi İslâm Ansiklopedisi (ìstanbul: TDV Yayınları, 1996), 14/389.

61 Erkan, "Siciller Işı̆̆ında Meşakkatli Bir İbadet Olan Hac ve Osmanlı Hacıları", 433-434.

62 Faruk Sümer, “Ağa”, Türkiye Diyanet Vakfi İslâm Ansiklopedisi (İstanbul: TDV Yayınları, 1988), 1/452.

63 Ferit Devellioğlu, Osmanlıca - Türkçe Ansiklopedik Lûgat (Ankara: Aydın Kitapevi Yayınları, 1999), "Halife", 318.

64 Mehmet Zeki Pakalın, Osmanlı Tarih Deyimleri ve Terimleri Sözlüğü (ìstanbul: Milli Eğitim Basımevi, 1983), 1/708-709.

65 Devellioğlu, "Halife", 318; Mehmet Zeki Pakalın, Osmanlı Tarih Deyimleri ve Terimleri Sözlüğü (İstanbul: Milli Eğitim Basımevi, 1983), “Halife”, 1/709. 
Seyyid isimlerinde rastlanan bir diğer tabir molla (monla) unvanıdır. Bu kapsamda 8 kişi (\%6.29) tespit edilmiştir. Kökeni itibariyle molla tabiri efendi, sahip, âmir anlamını ifade eden mevlâ kelimesinden geldiği ve kelimenin eş anlamlısı olarak monla, munla veya mulla biçimlerinin bulunduğu belirtilmektedir. ${ }^{66}$ Molla kelimesi, sözlük anlamı olarak âlim, fâdıl ve fakih anlamlarına gelmektedir. ${ }^{67}$ Molla tabiri, Osmanlı öncesinde olduğu gibi Osmanlı'da da ilmi bir unvan olarak kullanılmıştır ve birçok farklı zümreyi ifade edebilmiştir. ${ }^{68}$ Osmanlı Diyarbekiri'nde molla tabirinin bilumum medrese tahsili görmüş kişilere yönelik kullanılan ilmi bir unvan olduğu söylenebilir. ${ }^{69}$ Burada söz konusu olan seyyid mollaların da umumiyetle medrese mezunu din bilginleri oldukları kuvvetle muhtemeldir. Nitekim 17. yüzyılın ortalarında Diyarbekir'i ziyaret eden Evliya Çelebi meşhur seyahatnamesinde Diyarbekir'de din bilginlerine monla dendiğini ifade etmiştir. ${ }^{70}$

Seyyid isimlerinde rastlanan bir diğer lakap da mevlânâ olup bu kapsamda 8 (\%6.29) seyyid tespit edilmiştir. Osmanlı'da mevlânâ tabirinin sahibimiz, ${ }^{71}$ efendimiz, ${ }^{72}$

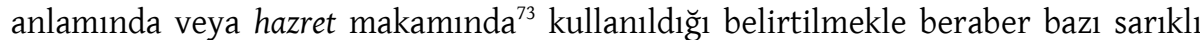
ilim adamlarının ve şeyhlerin lakabı olarak da kullanıldı̆̆ ifade edilmektedir. ${ }^{74}$ Íncelenen sicillerde bu lakabı kullanan seyyidlerin genelde kadılık, nâiblik, müftülük veya müderrislik gibi ilmi ve resmi bakımdan üst düzey görevler icra ettikleri gözlenmiştir. Dolayısıyla ilgili seyyidler arasında bu unvanın umumiyetle yüksek mevkilerde yer alan ve din bilgini olan seyyidler için kullanıldığı anlaşılmaktadır.

Osmanlı Diyarbekiri'nde kimi seyyidlerin taşıdıkları lakaplardan hâfız oldukları anlaşılmaktadır. Arapça'da korumak, ezberlemek manasındaki hıfz kökünden gelen hâfiz tabiri, sözlükte koruyan, ezberleyen anlamına gelip Kur'an'ın tamamını ezbere bilen kişiler için kullanılır. ${ }^{75}$ İlgili seyyidlerin sadece 7'sinin hâfız lakabını taşıdığı ve

${ }^{66}$ Hamid Algar, “Molla”, Türkiye Diyanet Vakfi İslâm Ansiklopedisi (İstanbul: TDV Yayınları, 2005), $30 / 238$.

67 Pakalın, "Molla”, 2/549.

68 Hamid Dabashi, "Mullah", The Oxford Encyclopedia of the Modern Islamic World, ed. John L. Esposito v.dğr. (New York: Oxford University, 1995), 3/177; J. Calmard, “Mollā”, The Encyclopedia of Islam (Leiden: E.J. Brill, 1980), 7/221-222.

69 Geniş bilgi için bk. Güler, "Osmanlı Sosyal Hayatında Mollalar”, 862.

70 Evliya Çelebi, Evliya Çelebi Seyahatnamesi, haz. Seyit Ali Kahraman-Yücel Dağlı (İstanbul: Yap1 Kredi Yayınlar1, 2010), 4/52; Günümüzde de Türkiye'nin Doğu ve Güneydoğu'sunda medrese tahsili görmüş din bilginleri molla (mela) olarak adlandırılmaktadır. bk. Martin Van Bruinessen, Ağa, Şeyh, Devlet, trc. Banu Yalkut (İstanbul: İletişim Yayınları, 2011), 310. Ayrıca bk. Halil Çiçek, Şark Medreselerinin Serencamı (İstanbul: Beyan Yayınları, 2009), 29 vd.

71 Pakalın, "Mevlana”, 2/498.

72 Pakalın, "Mevlana”, 2/498; Devellioğlu, “Mevlana”, 636.

73 Devellioğlu, "Mevlana”, 636.

74 Devellioğlu, "Mevlana”, 636.

75 Nebi Bozkurt, "Hâfız", Türkiye Diyanet Vakfi İslâm Ansiklopedisi, (İstanbul: TDV Yayınlar1, 1997), 15/74. 
bunun da oran olarak \%5.51'e tekabül ettiği ortaya çıkmıştır. Bu veri Osmanlı Diyarbekiri'nde kimi seyyidlerin hâfızlık yaptığını ve bu lakabı taşıdıklarını göstermekle beraber hâfızlığın seyyidler arasında pek yaygın olmadığını da ortaya koymaktadır. Ancak bu durumun seyyidlere mahsus olduğu düşünülmemelidir. Zira Evliya Çelebi meşhur seyahatnamesinde Diyarbekirliler' in hâfız yetiştirmekle beraber "Hıfz ilmine çalışan fâzıl olamaz" diye hıfz ilmine pek önem vermediklerini, daha çok diğer İslami ilimlerle iștigal edildiğini belirtmektedir. ${ }^{76}$

İncelenen kadı sicillerinde seyyidlerin sıklıkla gözlendikleri yerlerin başında şühûdü'l-hâl üyelikleri gelmektedir. Bu durum onların toplumsal statü ve saygınlıklarına yönelik dikkate değer bir görünümdür. Zira hâl şahitleri anlamına gelen şühûdü'l-hâl, kurulan mahkemenin aleniyetine ve kararının adaletine şahitlik eden sivil kişilerdir. En az iki kişiden oluşan şühûdü'l-hâl, davayı dinler, davanın usulüne muvafık olarak görüldüğüne tanıklık eder ve gerekli hâllerde kadı veya nâib tarafından görüşlerine başvurulabilirdi. Bu kişilerin konumu oldukça önemlidir. Zira onların hazır bulunmadığı veya hükmü imzalamadığı bir dava hukuken muteber sayılmazdı. ${ }^{77}$ Binaenaleyh böylesine önemli bir görevi ifa eden kişilerin umumiyetle toplumun ileri gelen ve saygın üyelerinden oluştuğu belirtilmektedir. ${ }^{78}$

\section{Seyyidlerin İktisadi İlişkileri}

Genel itibariyle şer'iyye sicillerinde toplum içerisinde cari olan iktisadi ilişkilere dair en fazla rastlanan işlemler arasında alım satım kayıtları gelmektedir. Bu durum Diyarbekir şer 'iyye sicilleri için de geçerlidir. Ancak anlaşılan odur ki ilgili dönemde seyyidler ve seyyidlerle alış veriş yapan kişiler alım satım işlemlerini mahkeme tarafindan tescil ettirmeyi pek tercih etmemişlerdir. Zira seyyidlerin taraflardan birini veya her ikisini teşkil ettiği alım satım kaydı sadece dört adettir. Bu işlemlerin ikisinde satıc1 ${ }^{79} \mathrm{ikisinde}$ de alıcı seyyidlerdendir. ${ }^{80}$ Her iki tarafin seyyidlerden oluştuğu bir alım satım kaydı da vardır. ${ }^{81}$ Mezkûr alım satım işlemlerinin tamamının ev, dükkân ve tarla gibi gayrimenkullerden oluştuğu gözlenmiştir.

Seyyidlerin taraf oldukları alım satım tescillerine pek rastlanmamış olması onların yer aldığı alım satımlarda ihtilaf ve sorunların pek yaşanmadığına, dolayısıyla tescil işlemine gerek duyulmadığına işaret etmektedir. Zira bu işlemlerde ihtilaf ve

76 Evliya Çelebi, Evliya Çelebi Seyahatnamesi, 4/43 vd.

77 Ekrem Buğra Ekinci, Osmanl Hukuku (İstanbul: Ar1 Sanat Yay., 2012), 376; Ronald C. Jennings, Studies on Ottoman Social History in the Sixteenth and Seventeenth Centuries: Women, Zimmis and Sharia Courts in Kayseri, Cyprus and Trabzon (İstanbul: The Isis Press, 1999), 257-258.

78 Jennings, Studies on Ottoman Social History in the Sixteenth and Seventeenth Centuries, 257-258; Mustafa Akdağ, Türkiye’nin İktisadî ve İçtimaî Tarihi (İstanbul: Yapı Kredi Yayınları, 2010), 437; Hülya Taş, “Osmanlı Kadı Mahkemesindeki “Şühûdü'l-Hâl” Nasıl Değerlendirilebilir?”, Bilig 44 (Kış, 2008), 34.

79 DŞS, 3775, 36a-1; DŞS, 3775, 36a-1.

80 DŞS, 3746, 5b-2; DŞS, 3775, 6b-1.

81 DŞS, 3774, 12b-2. 
sorunlara sık rastlanma gibi bir durum mevcut olsaydı seyyidlerin veya onlarla alış verişte bulunanların alış veriş muamelelerini kayıt altına aldırma temayül ve teamüllerinin olması beklenirdi. Binaenaleyh bu durum, ileride yeri geldikçe temas edilecek olan diğer bulguların da işaret ettiği üzere seyyidlerin genel itibariyle güvenilir ve saygın olduklarını ihsas etmektedir. Bu değerlendirmeyi destekleyen bir başka bulgu da alacak verecek davalarında ortaya çıkmaktadır. Bu kapsamda seyyidlerin taraf olduğu dava kayıtlarının çok az olduğu, az sayıdaki bu davalarda da genellikle seyyidlerin haklı olduğu ortaya çıkmıştır. Zira ilgili sicillerde seyyidlerin taraf olduğu alacak verecek meselesi kaynaklı dava kaydı sadece beş adettir. Döneme ait dikkate değer ve canlı görünümler sunması itibariyle bu vakalara kısaca değinmekte fayda vardir.

Bir vakada Seyyid İsa adlı kişi, Kasap Ömer'den alacağını dava etmiş ve davalının ikrarıyla davasını kazanmıştır. ${ }^{82}$ Bir başka belgede de Kazancı İkob adlı zimminin vârisleri, murislerine borçlu olduğunu iddia ettikleri Halepli Şişeci Seyyid Mehmed'e dava açmış, ancak davalının borcunun bulunmadığı şahitlerce ispat edildiğinden davayı mezkûr Seyyid kazanmıștır. ${ }^{83}$

Döneme ait belgeler, yukarıdaki vakada olduğu gibi seyyidlerin gayrimüslimlerle ticari ilişki kurduklarını ve bu kapsamda birbirlerine borçlarına mukabil rehin alıp verdiklerini göstermektedir. Örneğin Câmi-i Kebîr Mahallesi sakinlerinden Seyyid elHâc Abdülkadir Efendi'nin Şeyhmatar Mahallesi'nden müteveffa İstepan veled-i Keşiş Eyvanis ve Bedros veled-i İkob'dan alacağı olan borca karşılık rehin bırakılan evin satılması talebiyle varisler aleyhine dava açmıştır. Belgeye göre varisler mezkûr borcu ve rehni inkâr etmiş olsalar da davacı iddiasını şahitlerle ispatlayarak davayı kazanmıştır. ${ }^{84}$ Borç mukabili bırakılan rehne dair bir başka vakada da benzer biçimde rehnin varlığı varisler tarafından inkâr edilerek davacı seyyidin mağdur edildiği anlaşılmaktadır. Döneme ait Diyarbekir ahkâm defterinde yer alan bu davaya göre Seyyid Mehmed Baba adlı kişi vefat eden Hacı Abeş'e olan borcuna mukabil rehin verdiği evini borcunu ödeyerek geri almak istemiş, ancak varisler rehnin varlığını inkâr etmişlerdir. İlgili ferman davanın usulünce görülmesini emretmiş, ancak sonuca dair herhangi bir malumat belgelere yansımamıştır. ${ }^{85}$

Döneme ait sicillere yansıyan bir alacak davasında vefat etmeden önce esnaflık yapan Kavukçu Seyyid Mustafa'nın yine esnaftan Kavukçu Ebubekir Çelebi'ye olan borcunu başkalarının huzurunda ikrar ederek bu borcun varlığına tanık tuttuğu anlaşılmaktadır. Bu işlemin ileride borcun varlığına dair bir ihtilafın çıkması duru-

\footnotetext{
82 DŞS, 3798, 18a-5. 21 Cemâziyelevvel 1215 (10 Ekim 1800)

83 DŞS, 3803, 17a-3.15 Ramazan 1263 (27 Ağustos 1847)

84 DŞS, 3698, 31b-2.17 Muharrem 1217 (20 Mayıs 1802)

85 DAD, 6, 01-2. Evâil-i Zilka'de 1228 (26 Ekim-4 Kasım 1813)
} 
munda alacaklının mağdur olmaması amacıyla gerçekleştirildiği muhtemeldir. Nitekim mezkûr Seyyid'in vefat etmesiyle alacaklı bu tanıklığa istinaden hak iddiasında bulunmuş ve müteveffanın terekesinden borcun ödenmesine hükmolunmuştur. ${ }^{86}$

Döneme ait ahkâm defterlerine yansıyan bir belgede davacı gayrimüslim de olsa seyyidlerin mahkeme nezdinde herhangi bir ayrıcalığa tabi tutulmadığını ve adaletin gereğince hükmolunduğunu göstermiştir. Ayrıca bu vaka, nadiren de olsa seyyidlerin de başka insanlara karşs alacak verecek meselelerinde haksızlık yapabildiklerini göstermektedir. 1221 (1806) yllına ait konuya dair ilk belgede İstanbul'da sarraflık yapan Karabet ve Mıgırdıç adlı zimmilerin, borcunu ödememesi sebebiyle Diyarbekir'den Seyyid Sadullah Efendi'yi dava ettikleri anlaşılmaktadır. Diyarbekir Valiliği ve Kadıllğına hitap eden ilgili ferman, mezkûr davanın usulünce görülerek çözüme kavuşturulmasını emretmiş̧ir. ${ }^{87} 1223$ (1808) tarihli olan konuya dair bir başka fermanda ise mezkûr davanın görüldüğü, davacılar haklı bulunarak davalı seyyidin mallarının satıldığı ve mezkûr gayrimüslimlere olan borcun ödendiği anlaşılmaktadır. ${ }^{88}$ Borcun tahsili amacıyla seyyide ait malların satılmış olması, seyyidin işlerinin yolunda gitmediğine veya elinin sıkışık olduğuna işaret etmektedir.

Döneme ait bir başka vakada da yine bir zimminin davacı olduğu ve mahkemece haklılığına hükmedildiği anlaşılmaktadır. 7 Rebî̀ülevvel 1125 (3 Nisan 1713) tarihli belgeye göre Eto veled-i Haçador adlı zimmi, Seyyid Ahmed b. Mustafa'nın bir başkasına satmış olduğu ev üzerinde şüfa hakkı gereğince satın alma önceliğinin ihlal edildiğini iddia ederek kendisinden davacı olmuştur. Yargılama neticesinde kadı, zimmiyi haklı bulmuş ve satın alma önceliğinin davacı zimmide olduğuna hükmetmiştir. ${ }^{89}$

Döneme ait belgelerde seyyidlerin iktisadi güçlerine işaret eden pek fazla bilgi yer almamaktadır. Ancak bu hususta dolaylı olarak bazı çıkarımlarda bulunmak mümkündür. Örneğin döneme ait tereke kayıtları üzerinde yapmış olduğumuz incelemede 18 seyyid isminin terekelerde alacaklı veya borçlu olarak kaydedildiği ortaya çıkmıştır. Buna göre 14 seyyid terekelerde alacaklı, yani ilgili müteveffanın kendisine borçlu olduğu, dört seyyidin de müteveffanın kendisinden alacaklı olduğu anlaşılmaktadır. Dolayısıyla terekelerde isimleri geçen seyyidlerin yaklaşık \%78'i alacaklı konumdayken, sadece \%22'si borçlu konumdadır. Bu da seyyidlerin genel iktisadi durumlarına ışık tutması bakımından dikkate değer bir bulgudur. Bunun yanı sıra ilgili dönemde seyyidlerin icra etmiş oldukları meslekler, taşıdıkları lakap ve unvanlar, ${ }^{90}$ onların genel itibariyle toplumun orta ve üst tabakasında yer aldıklarına işaret etmektedir.

\footnotetext{
86 DŞS, 3774, 13b-2. 26 Şevvâl 1135 (30 Temmuz 1723)

87 DAD, 5, 276-1. Evâsıt-1 Şevvâl 1221 (1-9 Ocak 1807)

88 Detaylar için bk. DAD, 5, 312-1. Evâsıt-ı Rebî‘ülâhir 1223 (6-15 Haziran 1808)

89 DŞS, 3775, 3a-3.

90 bk. Tablo 1 ve Tablo 2.
} 


\section{Seyyidlere Yönelik Suçlar}

Seyyidlerin bilumum Osmanlı toplumunda Hz. Peygamber'in neslinden geliyor olmaları hasebiyle saygın bir konumlarının ve ayrıcalıklı bir statülerinin olduğu söylenebilir. ${ }^{91}$ Ancak bu saygın ve ayrıcalıklı sosyal konum onların içerisinde yer aldıkları toplumun gündelik hayatında hukuksuzluklara maruz kalmadıkları anlamına gelmemektedir. Zira döneme ait Diyarbekir şer iyye sicilleri ve bilhassa ahkâm defterleri bu kapsamda birçok hukuksuzluğun vaki olduğunu göstermiştir.

Osmanlı Diyarbekiri'nde seyyidlerin en çok sıkıntı yaşadıkları konuların başında vakıflardaki mütevellilik vazifelerine yönelik usulsüz müdahalelerin geldiği söylenebilir. Döneme ait ahkâm defterlerinde bu kapsamda dokuz ferman tespit edilmiştir. Bu belgelerde arz edilen problemlerin ortak noktası vakıf mütevelliliği yapan seyyidlere, bazı kimselerin yetkileri olmamasına rağmen mütevellilik görevi dâhilindeki vakıf işlerine müdahale etmeye çalışmalarıdır. Mütevelliler de görev ve yetkilerini ihlal eden bu gibi tacizler karşısında Dîvân-1 Hümâyûn'a şikâyette bulunarak bu hukuksuzlukların giderilmesini talep etmişlerdir. Dîvân'dan gönderilen fermanlar da Diyarbekir Valiliği ve Kadılığının gerekli tedbirleri alarak hukuksuzlukların giderilmesini emretmiştir. ${ }^{92}$

Mütevellilik görevlerine müdahalelerden sonra bu dönemde seyyidlere rahatsılık veren bir diğer hukuksuzluk da ehl-i örf taifesinden bazı kimselerin usulsüz biçimde seyyidlerden vergi tahsil etmeye çalışmalarıdır. Bilindiği üzere Osmanlı Devleti'nde seyyidler birtakım vergilerden muaftırlar. Bunların başında da raiyyet vergisi gelir. Zira bu muafiyet, Diyarbekir kadılığına gönderilen konuya dair fermanlarda "İstanbul nukabâsından yedlerinde ma'mûlün bih hüccet ve temessükleri var ise bu makûle sahîhu'n-neseb sâdât-1 kirâmdan rüsûm-1 ra'iyyet talebi hilâf-1 kânûndur" şeklinde açık biçimde bildirilmiştir. ${ }^{93}$ Ancak gayet açık olan bu hukuki muafiyet sipahi ve voyvoda gibi kimi görevlilerce ihlal edilmiş, ellerinde seyyidlik tezkireleri olmasına rağmen kendilerinden raiyyet rüsûmu ve emr-i şerîf olmaksızın tekâlif-i şâkka vergisi alınmaya çalışılmıştır. ${ }^{94}$ Döneme ait bir başka ferman maişetlerini sağlamak amaciyla koyun besiciliği yapan seyyidlerden aded-i ağnâm vergisinin alınmaması gerekirken bazı görevlilerin onlardan da usulsüz biçimde bu vergiyi tahsil etmeye çalıştıklarını bildirmiş ve bu hukuksuzluğa mâni olunmasını emretmiştir..$^{95}$

\footnotetext{
91 Kilıç, Osmanlıda Seyyidler ve Şerifler, 75-76.

92 DAD , 5, 234-2; DAD , 5, 362-1; DAD , 5, 362-2;DAD, 5, 362-3; DAD , 5, 375-1; DAD, 6, 31-2; DAD, 6, 91-1; DAD, 5, 188-2; DAD, 5, 150-1.

93 DAD, 5, 5-1; DAD, 7, 8-2.

94 DAD, 7, 8-2. Evâsıt-1 Şa'bân 1206 (14-22 Nisan 1792)

95 DAD, 6, 8-1. Evâsıt-1 Şa ‘bân 1206 (14-22 Nisan 1792)
} 
Usulsüz vergi tahsili şikâyetine binaen gönderildiği anlaşılan kimi fermanlarda isimleri belirtilen seyyidlerden avârız vergisi dışında herhangi bir verginin alınmaması emredilmiştir. ${ }^{96}$ Buna göre avârız vergisinin meşru olduğu ve tahsil edildiği anlaşılmaktadır.

Mezkûr fermanların birçoğunda belgelere konu edilen seyyidlerin "sahîhu'n-neseb sâdât-1 kirâmdan" oldukları, "isbât-1 neseb eyledikleri" ve ellerinde "İstanbul nukabâsından ma 'mûlün bih hüccet ve temessükleri" olduğu belirtilmiştir. ${ }^{97}$ Dolayısıyla Dîvân-1 Hümâyûn'un seyyidlik ispatı talep ettiği ve bunun için de İstanbul Nakipliğinin verdiği belgeyi kabul ettiği gözlenmiştir. Seyyidlikleri sabit olan Diyarbekir ahalisinden kişilerin de ihtiyaç halinde bu belgeleri tanzim ettirebildikleri anlaşılmaktadır.

Döneme ait Diyarbekir ahkâm defterleri, seyyidlerin mesleklerini icrada yaşadıkları bazı sıkıntılara dair de bilgiler ihtiva etmektedir. Yukarıda değinildiği gibi bu dönemde mesleki açıdan görece en büyük sıkıntıyı usulsüz müdahale girişimleri sebebiyle vakıf mütevelliliği yapanların yaşadıkları anlaşılmaktadır. Örneğin bir fermanda vakıf mütevelliliği yapan bir seyyidin görevine, bölgedeki şeyhlerden bazı kimselerin usulsüzce müdahale etmeye çalıştığından bu tacizin giderilmesi emrolunmuştur. ${ }^{98}$ Bunların haricinde Diyarbekir şehrinde mumculuk, ${ }^{99}$ müjdecilik ${ }^{100}$ ve nar kabuğu dövüp satma işini ${ }^{101}$ yapan seyyidlere, bu işi yapmakta olan diğer bazı kimselerin engel olmaya çalışıp kendilerini haksız ve yetkisiz biçimde taciz ettikleri de olmuştur. Konuya dair gönderilen fermanlar ile bu hukuksuzlukların önüne geçilmesi emrolunmuştur.

Daha önce de temas edildiği üzere Osmanlı taşrasında seyyidlerle ilgilenmeleri amacıyla nakîbüleşrâf kaymakamları bulunur ve bunların seyyidler üzerinde birtakım görev ve yetkileri olurdu. Döneme ait bir Diyarbekir kazası nâibine gönderilen bir fermanda, Diyarbekir nakîbüleşrâf kaymakamlığının bazı görev ve yetkilerinin ehl-i örften bazı kimseler tarafından çiğnendiği ve seyyidlere usule aykırı ceza verildiği ifade edilmiştir. Mezkûr belgeye göre ehl-i örften bazı kişiler nakîbüleşrâf kaymakamının bilgisi haricinde ve kanunsuz biçimde kimi seyyidleri tutuklayıp hapsetmişlerdir. Fermanda bu hukuksuzluğun giderilmesi emrolunmuştur. ${ }^{102} \mathrm{Bu}$ belge Osmanlı Diyarbekiri'nde nakîbüleşrâf kaymakamlığının görev ve yetkilerine işaret etmekle birlikte zaman zaman bu görev ve yetkilerin kimi ehl-i örf mensupları tarafından çiğnenebildiğini göstermesi bakımından da dikkat çekicidir.

\footnotetext{
96 DAD, 5, 138-5; DAD , 5, 138-6.

97 DAD, 5, 5-1; DAD, 6, 8-1; DAD, 7, 8-2.

98 DAD, 5, 188-2. Evâhir-i Şevvâl 1217 (14-22 Şubat 1803)

99 DAD, 8-63-2. Evâhir-i Ramazan 1259 (15-24 Ekim 1843)

100 DAD, 6, 27-2. Evâil-i Rebî‘ülâhir 1232 (10-18 Mart 1817)

101 DAD, 5, 366-1. Evâhir-i Cemâziye'l-âhir 1227 (2-10 Temmuz 1812)

102 DAD, 6, 36b-2. Evâhir-i Cemâziyelevvel 1234 (18-27 Mart 1819)
} 
Osmanlı Diyarbekiri'nde seyyidlerin gasp, yaralama ve bilhassa cinayet gibi ağır nitelikli suçlara maruz kalıp kalmadıkları merak konusu olabilir. Gerek ahkâm defterleri gerekse şer'iyye sicilleri üzerinde yapmış olduğumuz inceleme, ilgili dönem Diyarbekiri'nde cinayete kurban gitmiş olan sadece bir nakîbüleşrâf kaymakamina işaret etmektedir. Söz konusu vakada nakîbüleşrâf kaymakamının, kendi evinde dövülerek öldürüldüğü ve katilin de firar ettiği anlaşılmaktadır. Belgede cinayet sebebine değinilmemiştir. Ancak konuya dair gönderilen fermanda katilin ivedilikle yakalanıp yargılanmak üzere İstanbul'a gönderilmesi emrolunmuştur. ${ }^{103}$

Döneme ait bir başka belgede ise bir cinayet teşebbüsü ve gasp vaki olmaktadır. Seyyid Ahmed b. İbrahim ve diğer bazı kişiler Kâsımî ve Kadıkendî köyleri arasında gece vakti karpuz getirirken bir grup gayrimüslim eşkıyanın saldırısına maruz kalmışlardır. Bu saldırıda Seyyid Ahmed başına aldığı kılıç darbesiyle yaralanmış ve grubun dört büyükbaş hayvanı gasp edilmiştir. ${ }^{104}$

İlgili dönemde kaza kurşunu sonucu yaralanan bir seyyide de rastlanmıștır. Seyyid Halil b. Receb mahkemeye müracaat ederek Çukadâr Halil b. Yusuf'un bir önceki gece bostanda uyurken mezkûr Halil'in tüfek ile kendisini sağ avurdundan vurup aşağ1 dişlerinden birini söktügünü iddia etmiş ve kendisinden davacı olmuştur. Davalı Halil de savunmasında, gece bostanda uyurken tüfeğinin kazara ateş aldığını ve mezkûr seyyidi vurduğunu ikrar etmiştir. Vaka, hüküm zikredilmeksizin kayıt altına alınmıştır. ${ }^{105}$

Döneme ait ahkâm defterleri, az da olsa Osmanlı Diyarbekiri'nde seyyidlerin tımar ${ }^{106}$ sahibi olabildiklerini ve kendi tasarruflarında olan topraklara bazı kimselerin usulsüzce müdahale girişiminde bulunabildiklerini göstermektedir. Bunun yanı sıra bir seyyidin, özel mülk konumunda olan gayrimenkulüne bey unvanlı bir şahsın hukuksuzca el koymaya çalıştı̆̆ı da şikâyete konu olmuş ve Dîvân-1 Hümâyûn olayın çözüme kavuşturulmasını emretmiştir. ${ }^{107}$

\section{Seyyidlerin İşledikleri Suçlar}

Döneme ait şer'iyye sicilleri ve ahkâm defterleri Osmanlı Diyarbekiri'ndeki seyyidlerin işledikleri veya itham edildikleri suçlara dair bazı bilgiler sunmaktadır. Örneğin Evâhir-i Muharrem 1210 (7-16 Ağustos 1795) tarihli bir fermanda Şeyhzade Seyyid İbrahim adlı şahsın çok sayıda suça karıştığı ifade edilmektedir. Mezkûr belgede, Şeyhzade Seyyid İbrahim'in Diyarbekir'in Şâfi'î Müftüsü Seyyid Mahmud'un

\footnotetext{
103 DAD, 5, 167-2. Evâhir-i Zilhicce 1212 (6-15 Haziran 1798)

104 DŞS, 3746, 4b-2. 5 Zilka'de 1136 (26 Temmuz 1724)

105 DŞS, 3774, 12b-1. 4 Zilhicce 1135 (5 Eylül 1723)

106 DAD, 5, 155-2. Evâhir-i Rebîüülevvel 1212 (13-22 Eylül 1797) ; DAD, 5, 166-2. Evâhir-i Şevvâl 1212 (8-16 Nisan 1798); DAD, 5, 310-2. Evâhir-i Rebîüülevvel 1223 (17-26 Mayıs 1808)

107 DAD, 5, 181-2.
} 
köyünü ve evini basıp 11 adamını öldürüp 50 kîselik malını gasp ettiği, ahaliye yönelik birçok zulüm işlediği, Hanefî müftüsünün evine silahlı adamlar göndererek müftünün oğlunun 200 küçükbaş hayvanını gasp ettiği ve daha birçok suça karıştığı ifade edilmiștir. Mezkûr iddialar mezkûr şâfi î Müftüsü ve ahaliden 15 kişinin arzuhâli ile Dîvân-1 Hümâyûn'a iletilmiş ve Dîvân da ilgili ferman ile davanın görülerek adaletin tesisini emretmiştir. ${ }^{108}$ Yine Evâhir-i Safer 1210 (6-15 Eylül 1795) tarihli bir başka fermanda da Diyarbekir Kale Camii Hatibi Seyyid Halil b. Mehmed'in görevini terk ederek eşkıya ile işbirliği yaptığı iddiası dile getirilmiştir. Bu iddia ile mezkûr hatibin yerine Hâfız İsmail Halîfe'nin tayin edildiği bildirilmiş ve mezkûr hatib aleyhindeki iddiaların tahkik edilerek durumunun kendilerine bildirilmesi emrolunmuştur. ${ }^{109}$

Döneme ait șer'iyye sicillerinde yer alan 2 Zilka'de 1136 (23 Temmuz 1724) tarihli belgede bir seyyidin tecavüz ile suçlandığı anlaşılmaktadır. Mezkûr belgeye göre Diyarbekir'in Çüngüş Nahiyesi Ebu Tahir köyünden Rahime bt. Mustafa adlı kadın mahkeme huzurunda Seyyid Ömer b. Mehmed aleyhine davacı olmuştur. Davacı kadın geçen sonbaharda bağından dönerken Seyyid Ömer'in, yoluna çıarak kendisine tecavüz ettiğini, sonra da "sükût eyle, ben seni kendime nikâh ederim" diyerek evine götürdüğünü ve dört ay evinde tuttuğunu dile getirmiştir. Mezkûr Rahime bu süre zarfında hamile kaldığını ve kendisinin bu süre boyunca nikâhlanmayarak oyalandığını ifade etmiştir. Dört ay sonra hamile kaldığı çocuğu düşük yapınca da Seyyid Ömer'in kendisine "ben seni nikâh eylemem" dediğini iddia ederek kendisinden davacı olmuştur. Mezkûr iddiaları davalının reddetmesi üzerine davacıdan delil talep edilmiştir, ancak kendisi bunu sağlayamamıştır. İddianın ispatlanamaması üzerine mezkûr Seyyid Ömer, "Zevci olmayan Hind'in hamli zâhir oldukda mezbûre hamlim Zeyd'dendir demesiyle Zeyd şer'an zânî olmuş olur mu? Cevâb: Olmaz." fetvasını ve muteber fikıh kitaplarından olan el-Mebsût'a göre "Bir davanın mücerred bir isnat ile sabit olmayacağı" prensibini suçsuzluğunu savunma adına mahkemeye sunmuştur. Hâkim de hüküm beyan etmeksizin ifadeleri kayıt altına almıştır. ${ }^{110}$ Mezkûr vakada iddiaların ispatına yönelik gerek davacının kendisinin gerekse aile veya akrabalarının herhangi bir tanık veya delil sunamamış olmaları dikkat çekicidir. Bu durumda davalının hukuken masum olduğu mahkeme tarafından tescil edilmiş olmaktadır.

Döneme ait belgeler, seyyidlerin suç hadiselerine oldukça nadir biçimde karıştıklarını veya şikâyete konu edildiklerini ortaya koymaktadır. Onlara yönelik oldukça az olan suç isnatlarının bir kısmı da mahkeme huzurunda ispat edilememiştir. Dolayısıyla kimi suçlar, iddia düzeyinde olup ispatlı değildir. İddia düzeyindeki suçların da sabit olduğu varsayılsa dahi seyyidlerin işledikleri suçların nadiren vuku bulduğu ve istisnai durumlar arz ettiği ortaya çıkmaktadır. Seyyidlerin işledikleri suçların

\footnotetext{
108 DAD, 5, 111-1.

109 DAD, 5, 116-2.

110 DŞS, 3746, 3a-2.
} 
veya onlara yönelik suç iddialarının bu denli az olması onların sosyal hayat içerisindeki hüsnü ahvâllerine, bir diğer ifadeyle doğruluk ve güvenilirliklerine yönelik oldukça kıymetli bir bulgudur.

\section{Değerlendirme ve Sonuç}

Toplumsal rol ve konumlarına bağlı olarak seyyidlerin ilgili dönemdeki sosyal görünürlüklerinin yüksek olduğu tespit edilmiştir. Bu dönemde seyyidlerin, müderrislikten kadılığa, esnaflıktan eyalet valiliğine kadar oldukça çeşitli mesleki sahalarda etkinlik gösterdikleri anlaşılmıştır. Din hizmetleri başta olmak üzere yargı hizmetlerinde, idari görevlerde ve esnaflık sahasında yoğun olarak varlık göstermişlerdir. Ancak onlar, sadece mesleki olarak değil sosyal rol ve konumları itibarıyla da toplumun ileri gelenleri arasındadır. Dolayısıyla seyyidlerin sosyal hayatın merkezi konumunda yer alan saygın ve etkin bir toplumsal grup olduğu söylenebilir.

Araştırmada ortaya çıkan bulgular, Osmanlı Diyarbekiri'nde şerif unvanının değil de hem Hz. Hasan hem de Hz. Hüseyin'in nesli için seyyid unvanının kullanıldığını ortaya koymuştur. Dolayısıyla seyyidler arasında Hasenî ve Hüseynî oluşa göre seyyidlik-şeriflik ayrımına rastlanmamıştır. Bunun yanı sıra çok sayıda kadının seyyid ailelerinden gelmelerine rağmen onlar için genelde seyyide veya şerife unvanlarının kullanılmadığı tespit edilmiştir.

Bu dönemde seyyidlerin icra etmiş oldukları meslekler, taşıdıkları lakap ve unvanlar onların genel itibariyle toplumun orta ve üst tabakasında yer aldıklarına işaret etmiştir. Mali açıdan da belgelere daha çok borç veren veya alacaklı kişiler olarak yansımışlardır.

İncelenen belgeler, seyyidlerden herhangi bir kimsenin davalık bir durumu söz konusu olduğunda onların da şer î mahkeme huzuruna çıkartılarak yargılandıklarını ortaya koymuştur. Ancak bu süreçte mahkemeye getirilme, tutuklanma, hapis, tedib veya icrası lazım gelen herhangi bir şer'î hüküm söz konusu olduğunda bunu icra etme vazife ve yetkisinin nakîbüleşrâf kaymakamlarında olduğu anlaşılmıştır. Hz. Peygamber'in soyunu temsil etmeleri itibariyle devletin seyyidlere büyük önem atfettiği ve ihtiram gösterdiği ortaya çıkmıştır. Fakat haksız bir eylemleri sadır olduğunda kanun önünde diğer Müslüman ve gayrimüslimlerle eşit statüde yargılanmışlardır. Kendilerine özel bir değer atfedilen seyyidlerin, bilhassa gayrimüslimlerle karşı karşıya geldiklerinde onlarla eşit statüde yargılanmaları ve yeri geldiğinde adaletin gereğince seyyidlerin aleyhine hükmolunması, Osmanlı sosyal hayatına ve adalet sistemine dair dikkat çekici bir görünümdür.

Devlet nezdinde olduğu gibi toplum nezdinde de seyyidlere özel bir değer atfedildiği ve kendilerinin saygın bir konumda olduğu ortaya çıkmıştır. Ancak bu dönemde seyyidlerin ehl-i örften veya reayadan bazı kişilerce zaman zaman birtakım hukuksuzluklara maruz kalabildikleri de olmuştur. Bunların başında vakıflardaki mütevellilik vazifelerine yönelik usulsüz müdahaleler gelmektedir. Bundan sonra 
gelen bir diğer hukuksuzluk da ehl-i örf taifesinden bazı kimselerin usulsüz biçimde seyyidlerden vergi tahsil etmeye çalışmalarıdır. Bu dönemde esnaflık gibi işlerle uğraşan bazı seyyidlerin mesleklerini icrada yaşadıkları birtakım sıkıntılar da olmuştur. Bunlar da daha çok aynı işi yapmakta olan bazı kimselerin menfaatleri icabı seyyidleri haksız ve yetkisiz biçimde taciz etmeleriyle ortaya çıkmıştır. Gündelik hayatta karşılaşılan ve dönemin şartları itibariyle sıradan addedilebilecek bu sorunların d1şında seyyidlere yönelik gasp, cinayet, darp ve hırsızlık gibi suçların yok denecek kadar az olduğu gözlenmiştir.

Zikrolunduğu üzere seyyidlere yönelik suçlar pek fazla değildir. Ancak bu dönemde seyyidlerin işledikleri veya itham edildikleri suçlar yok denecek kadar azdır. Bir diğer ifadeyle bu dönemde seyyidler az da olsa birtakım hukuksuzluklara maruz kalmışlardır. Ancak seyyidlerden sadır olan suçlar bunlara nispetle çok daha azdır. $\mathrm{Bu}$ da seyyidlerin hüsnü ahvâllerine yönelik dikkate değer bir görünümdür. Netice itibariyle seyyidlerin, toplum içerisinde umumiyetle saygın ve seçkin bir konumda yer almakla birlikte Hz. Peygamber'in soyunu temsil etmeleri itibariyle taşıdıkları manevi sorumluluğa muvafık bir yaşam tarzına sahip oldukları ifade edilebilir.

Çıkar Çatışması / Conflict of Interest: Yazar çıkar çatışması olmadığını beyan etmiştir. / The author declared that there is no conflict of interest.

Finansal Destek / Grant Support: Yazar bu çalışma için finansal destek almadığını beyan etmiştir. / The author declared that this study has received no financial support. 


\section{Kaynakça}

Adak, Abdurrahman. “Güneydoğu Anadolu'da Seyyidler”. Marife 3 (2004), 365-376.

Ağca, Sevgi. “Osmanlı Devleti'nde Nakîbü'l-Eşrâflık Müessesesi”. Osmanlı Devleti’nde Ehl-i Beyt Sevgisi. 45-65. İstanbul: Nefes Yay., 2008.

Ahmet Rifat Efendi. Osmanlı Toplumunda Sâdât-ı Kirâm ve Nakîbü'l-Eşrâflar. Haz. Hasan Yüksel, Fatih Köksal. Sivas: y.y. 1998.

Akdağ, Mustafa. Türkiye’nin İktisadî ve Içtimaî Tarihi. İstanbul: Yapı Kredi Yayınları, 2010.

Akdemir, M. Sadık. “Şeriyye Sicillerine Göre XVII. Yüzyılda Isparta'da Nakîbü'l-Eşrâf Kaymakamlığı ve Seyyidler”. Arayışlar, İnsan Bilimleri Araştırmaları 17 (2007), 143177.

Akgündüz, Ahmet. Şeri’yye Sicilleri. 2 Cilt. İstanbul: Türk Dünyası Araştırmaları Vakfı, 1988.

Algar, Hamid. "Molla”. Türkiye Diyanet Vakfi İslâm Ansiklopedisi. 30/238-239. İstanbul: TDV Yayınları, 2005.

Aydın, Mehmet Âkif - Hamîdullah, Muhammed. "Köle". Türkiye Diyanet Vakfı İslâm Ansiklopedisi. 26/246-248. Ankara: TDV Yayınları, 2002.

Bozkurt, Nebi. "Hâfız". Türkiye Diyanet Vakfi İslâm Ansiklopedisi. 15/74-78. İstanbul: TDV Yayınları, 1997.

Bruinessen, Martin Van. Ağa, Şeyh, Devlet. Trc. Banu Yalkut. İstanbul: İletişim Yayınlar1, 2011.

Buzpınar, Ş. Tufan. "Nakîbüleşraf”. Türkiye Diyanet Vakfi İslâm Ansiklopedisi. 32/322324. İstanbul: TDV Yayınları, 2006.

Calmard, J. "Mollā". The Encyclopedia of Islam. 7/221-222. Leiden: E.J. Brill, 1980.

Çetin, Osman. Sicillere Göre Bursa'da İhtida Hareketleri ve Sosyal Sonuçları (1472-1909). Ankara: Türk Tarih Kurumu Basımevi, 1994.

Çiçek, Halil. Şark Medreselerinin Serencamı. İstanbul: Beyan Yayınları, 2009.

Dabashi, Hamid. "Mullah”. The Oxford Encyclopedia of the Modern Islamic World. Ed. John L. Esposito vd. 3/177. New York: Oxford University, 1995.

Devellioğlu, Ferit. Osmanlıca - Türkçe Ansiklopedik Lûgat. Ankara: Aydın Kitapevi Yayınları, 21. Baskı, 1999.

Diyarbakır Ahkâm Defterleri (DAD), Başbakanlık Osmanlı Arşivi (BOA), Katalog No: 989, Sira No: 5, 6, 7, 8, 9. 
Diyarbekir (Âmid) Şer'iyye Sicilleri (DŞS), Başbakanlık Osmanlı Arşivi (BOA), Defter No: 3789, 3828, 3709, 3712, 3754, 3756, 3744, 3714, 3773, 3796, 3743, 3757, 3675, $3753,3725,3785,3823,3749,3797,3798,3698,3750,3716,3787,3746,3745,3685$, 3742 , 3718, 3767, 3741, 3791, 3726, 3800, 3731, 3747, 3804, 3760, 3768, 3803, 3707, $3680,3702,3774,3775$.

Diyarbekir Şer'iyye Sicilleri Âmid Mahkemesi. Ed. Ahmet Zeki İzgöer. 10 Cilt. Diyarbakır: Dicle Üniversitesi İlahiyat Fakültesi Yayınları, 2013.

Dîvân-1 Hümâyûn Sicilleri Diyarbekir Ahkâm Defterleri. Ed. Ahmet Zeki İzgöer, 3 Cilt. Diyarbakır: Dicle Üniversitesi İlahiyat Fakültesi Yayınları, 2016.

Ekinci, Ekrem Buğra. Osmanlı Hukuku. İstanbul: Arı Sanat Yay., 2012.

Erginli, Zafer. “Osmanlı Devleti'nin İlk Resmî Nakîbü'l-Eşrâf'1 Olan Bir Derviş: Seyyid Nattâ”. 138-148. Gümüşlü’den Günümüze Osmanl Kültüründe Bursa. Bursa: y.y., 2003.

Erkan, Nevzat. "Siciller Işığında Meşakkatli Bir İbadet Olan Hac ve Osmanlı Hacıları". Manisa Celal Bayar Üniversitesi Sosyal Bilimler Dergisi. 3 (2019), 423-451.

Eser, Mithat. Abbasilerin İlk Döneminde Seyyidler ve Şerifler. İstanbul: İz Yayıncılık, 2014.

Evliya Çelebi. Evliya Çelebi Seyahatnamesi. Haz. Seyit Ali Kahraman - Yücel Dağlı. İstanbul: Yapı Kredi Yayınları, 2010).

Güler, Ümit. “Osmanlı Sosyal Hayatında Mollalar: 18. ve 19. yy. Diyarbekir Örneği”. e-Şarkiyat İlmi Araştırmalar Dergisi. 11/2 (Ağustos 2019), 860-895.

Gümüş, Ercan. "Sâdât: 17. ve 18. Yüzyılda Diyarbekir Eyaleti'nde Seyyidler, İmtiyazları ve Sosyo-Ekonomik Konumları Hakkında Bir Değerlendirme”. Sosyal, Beşeri ve İdari Bilimler Alanında Yenilikçi Yaklaşımlar. Ed. Kürşat Özdaşlı vd. 3/569-605. Ankara: Gece Akademi Yay., 2018.

Güney, Emin. Sivas Tereke Defterlerinden Hareketle Sivas'ta Seyyidlerin Sosyo-Ekonomik Hayatı (1825-1850 Yılları). İstanbul: Marmara Üniversitesi, Sosyal Bilimler Enstitüsü, Yüksek Lisans Tezi, 2015.

Işık, Ayhan. “Çankırı'nın Manevî Fâtihleri: Çankırı Seyyidleri”. Alevilik Araştırmaları Dergisi 1 (2017), 77-118.

Işık, Ayhan. Meşîhat Arşivi Belgeleri Işığında Seyyidler ve Nakîbü'l-Eşrâflık Müessesesi. İstanbul: İstanbul Üniversitesi, Sosyal Bilimler Enstitüsü, Doktora Tezi, 2013.

Jennings, Ronald C.. Studies on Ottoman Social History in the Sixteenth and Seventeenth Centuries: Women, Zimmis and Sharia Courts in Kayseri, Cyprus and Trabzon. İstanbul: The Isis Press, 1999.

Keskin, Necat. Akışkan Kimlikler: Etnik ve Dini Kimlik Arasında Becirman Seyyidleri. Ankara: Hacettepe Üniversitesi, Sosyal Bilimler Enstitüsü, Doktora Tezi, 2014. 
Kılıç, Rüya. Hilafet Mücadelelerinin, İslam Tarihinde ve Osmanlı İmparatorluğu'nda Toplumsal Yapıdaki İzdüşümü: Seyyid ve Şerifler. Ankara: Hacettepe Üniversitesi, Sosyal Bilimler Enstitüsü, Yüksek Lisans Tezi, 1994.

Kılıç, Rüya. Osmanlı Devleti’nde Seyyidler ve Şerifler (XIV-XVI. Yüzyıllar). Ankara: Hacettepe Üniversitesi, Sosyal Bilimler Enstitüsü, Doktora Tezi, 2000.

K1lıç, Rüya. Osmanlıda Seyyidler ve Şerifler. İstanbul: Kitap Yayınevi, 2016.

Köprülü, Orhan F. "Efendi”. Türkiye Diyanet Vakfi İslâm Ansiklopedisi. 10/455-456. İstanbul: TDV Yayınları, 1994.

Küçükaşc1, Mustafa Sabri. "Tarihi Süreçte Seyyid ve Şerif Kavramlarının Kullanımı”. Osmanlı Araștırmaları 33/33 (2009), 87-129.

Küçükaşc1, Mustafa Sabri. “Seyyid”. Türkiye Diyanet Vakfi İslâm Ansiklopedisi. 37/40-43. İstanbul: TDV Yayınları, 2009.

Ortaylı, İlber. Hukuk ve İdare Adamı Olarak Osmanlı Devleti'nde Kadı. İstanbul: Kronik Yay., 2. Bask1, 2016.

Ortayl1, İlber. "Kadı". Türkiye Diyanet Vakfi İslâm Ansiklopedisi. 24/67-93. İstanbul: TDV Yayınları, 2001.

Ögüt, Salim. “Hac”. Türkiye Diyanet Vakfi İslâm Ansiklopedisi. 14/389-397. İstanbul: TDV Yayınları, 1996.

Özcan, Abdülkadir. “Osmanlı'da Seyyidler ve Şerifler”. Derin Tarih 5 (Mart 2016), 132136.

Öztürk, Nazif. “Mütevelli”. Türkiye Diyanet Vakfi İslâm Ansiklopedisi. 32/217-220. İstanbul: TDV Yayınları, 2006.

Pakalın, Mehmet Zeki. Osmanlı Tarih Deyimleri ve Terimleri Sözlüğü. 3 Cilt. İstanbul: Milli Eğitim Basımevi, 1983.

Sakaoğlu, Necdet. “Seyyidlik Sarığı Sarmak”. Tarih ve Toplum 5 (1985), 107-108.

Sarıcık, Murat. "Ebussuûd Efendi'nin Fetvâlarında Seyyidler”. Süleyman Demirel Üniversitesi İlahiyat Fakültesi Dergisi 11 (2004), 63-90.

Sarıcık, Murat. "Nakîbü'l-eşraf Abdülkadir Efendi Tarafından Verilen 1008/1600 Tarihli Siyâdet Hücceti”. EKEV Akademi Dergisi 35 (2008), 113-126.

Sarıcık, Murat. “Osmanlı Devleti'nde Nakîbü’l-Eşrâflık Kurumu”. Türkler 10/385-393. Ankara: y.y. 2002.

Sarıcık, Murat. Osmanlı İmparatorluğunda Nakîbü'l-Eşraflık Müessesesi. Ankara: TTK Yayınları, 2003. 
Sümer, Faruk. “Ağa”. Türkiye Diyanet Vakfi İslâm Ansiklopedisi. 1/452. İstanbul: TDV Yayınları, 1988.

Şimşek, Muttalip. “Osmanlı Devleti'nde Nakîbüleşraflık Müessesesi ve Bu Müesseseye Bağlı Kaymakamlıklar (19. Yüzyıl)”. Tarihin Peşinde -Uluslararası Tarih ve Sosyal Araştırmalar Dergisi 19 (2018), 401-431.

Taş, Hülya. "Osmanlı Kadı Mahkemesindeki "Şühûdü'l-Hâl” Nasıl Değerlendirilebilir?”. Bilig 44 (Kış 2008), 25-44.

Tuna, Sevda. Osmanlı Dönemi Ankara'sında Sosyo - Ekonomik ve Demografik Açıdan Seyyide ve Şerifeler (M.1786-1835). Sivas: Cumhuriyet Üniversitesi, Sosyal Bilimler Enstitüsü, Yüksek Lisans Tezi, 2013.

Uğur, Yunus. "Şer'iyye Sicilleri”. Türkiye Diyanet Vakfi İslâm Ansiklopedisi. 39/8-11. İstanbul: TDV Yayınları, 2010.

Uzunçarşıll, İsmail Hakkı. Mekke-i Mükerreme Emirleri. Ankara: Türk Tarih Kurumu, 1984.

Uzunçarşılı, İsmail Hakkı. Osmanlı Devletinin İlmiye Teşkilatı. Ankara: Türk Tarih Kurumu, 2014.

Uzunçarşıll, İsmail Hakk1. “Osmanlılar' da Nakîbü'l-Eşraflık”. Haz. Ali Dadan. Marife 3 (2004), 431-438.

Uzunçarşıll, İsmail Hakkı. “Şer'î Mahkeme Sicilleri”. Ülkü Halkevleri Dergisi 5/29 (Temmuz 1935), 365-368.

Yaman, T. Mümtaz. “Şer‘î Mahkeme Sicilleri”. Ülkü Halkevleri Dergisi 12/68 (illk Teşrin 1938), 153-164.

Yılmazçelik, İbrahim. XIX. Yüzyılın İlk Yarısında Diyarbakır (1790-1840). Ankara: Türk Tarih Kurumu Yay., 2014.

Yörük, Saim. “Adanalı Seyyidler Hakkında Sosyal ve Ekonomik Açıdan Bazı Değerlendirmeler (1701-1750)”. Sosyal Bilimler Araştırma Dergisi 18 (2011), 1-22. 


\section{Ek: Seyyidlere Dair Örnek Sicil Belgeleri}

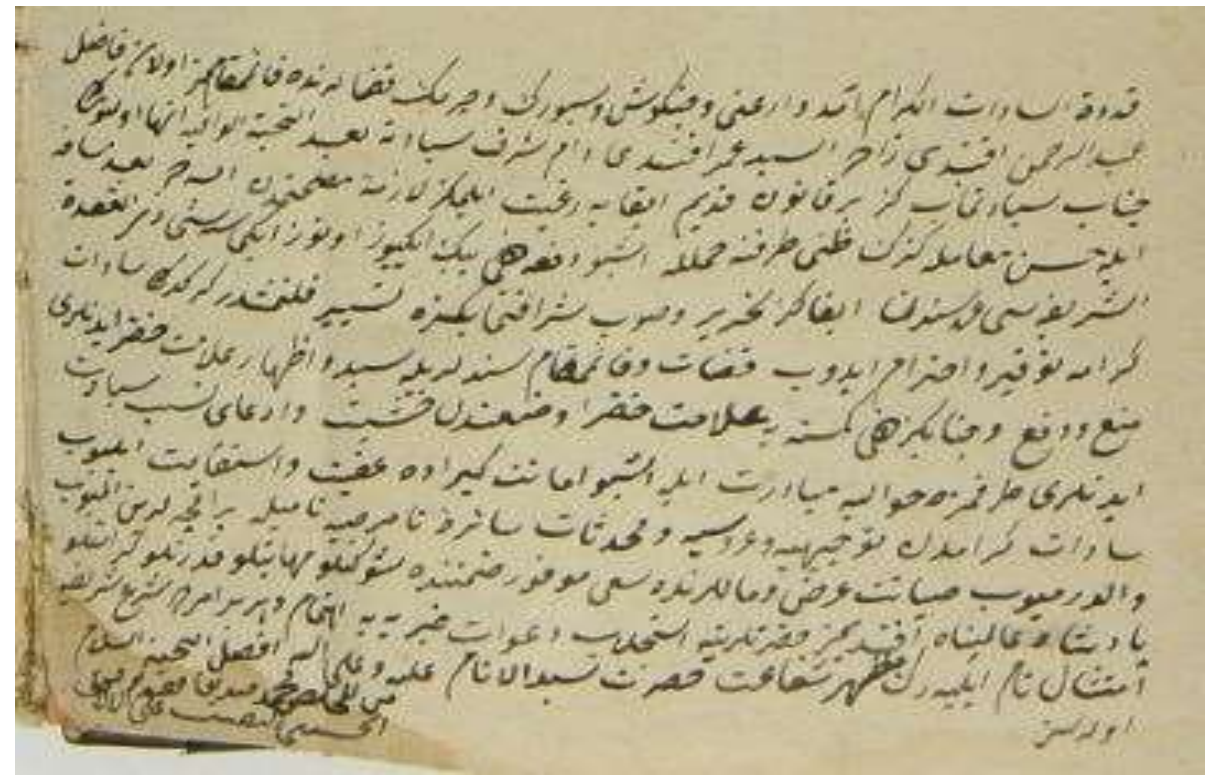

Belge 1: Diyarbekir, Ergani, Çüngüş, Siverek ve Çermik kazaları için nakîbüleşrâf kaymakamı tayin edilen Seyyid Ömer Efendi'nin görev ve sorumluluklarının beyanı, bk. DŞS, 3787, 2b-1. 1 Zilkade 1232 (12 Eylül 1817). 


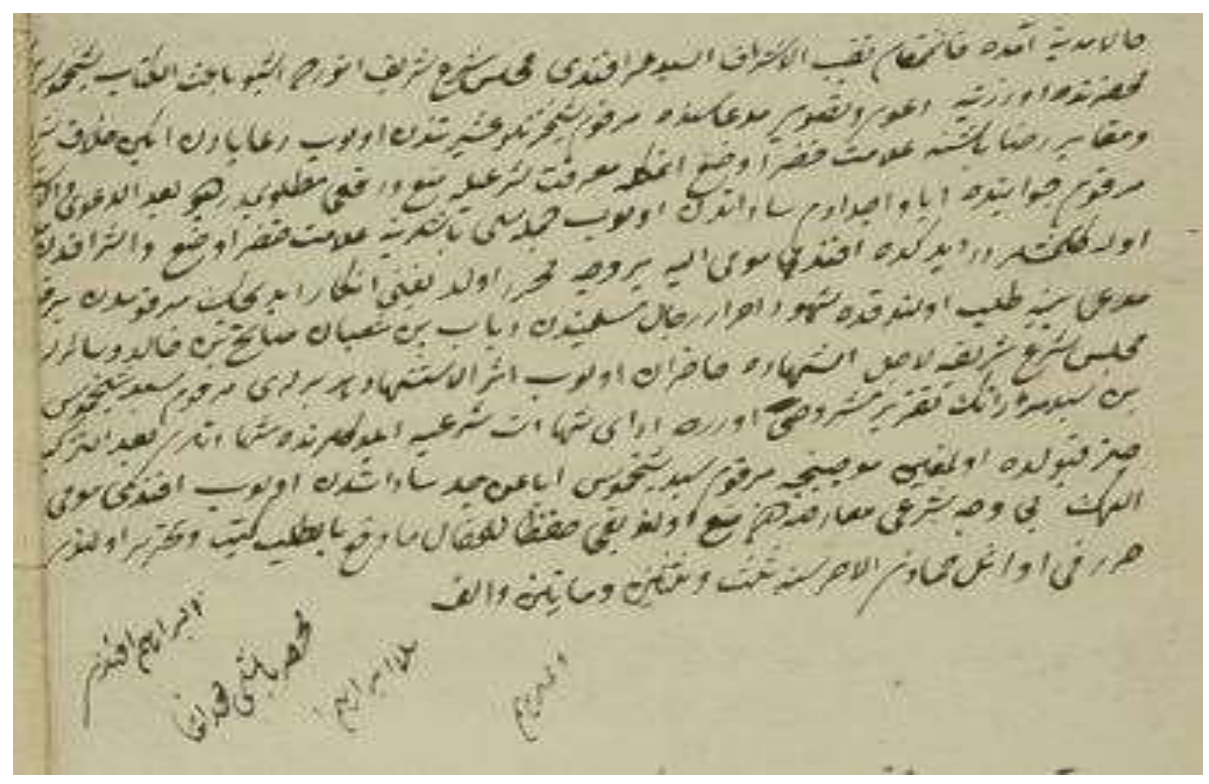

Belge 2: Âmid Nakîbüleşrâf Kaymakamı Seyyid Ömer Efendi'nin, Şeyhmus b. Seyyid Mirza'yı seyyid alameti olan yeşil sarık sarmasından ötürü dava etmesiyle, davalının seyyidlerden olduğunu şahitler vasitasıyla ispatlaması, bk. DŞS, 3787, 17b-2. Evâil-i Cemâziyelâhir 1233 (8-17 Nisan 1818). 


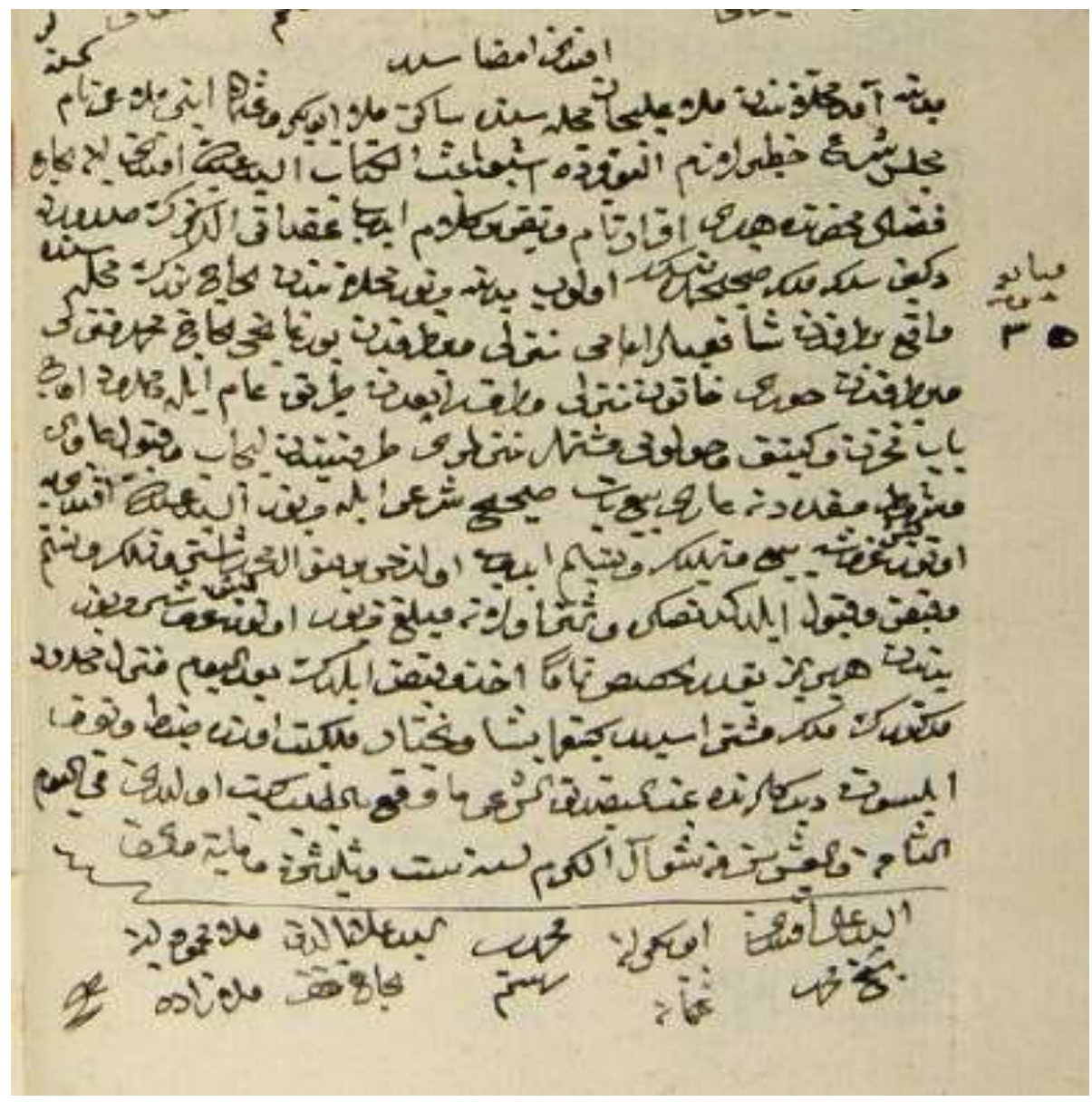

Belge 3: Molla Ebubekir ve Osman adlı kardeşlerin Hacı Büzürg Mahallesi'ndeki evlerini müştemilâtıyla birlikte Seyyid Abdullah Efendi'ye satmaları, bk. DŞS, 3746, 5b-2. 28 Şevvâl 1136 (20 Temmuz 1724). 


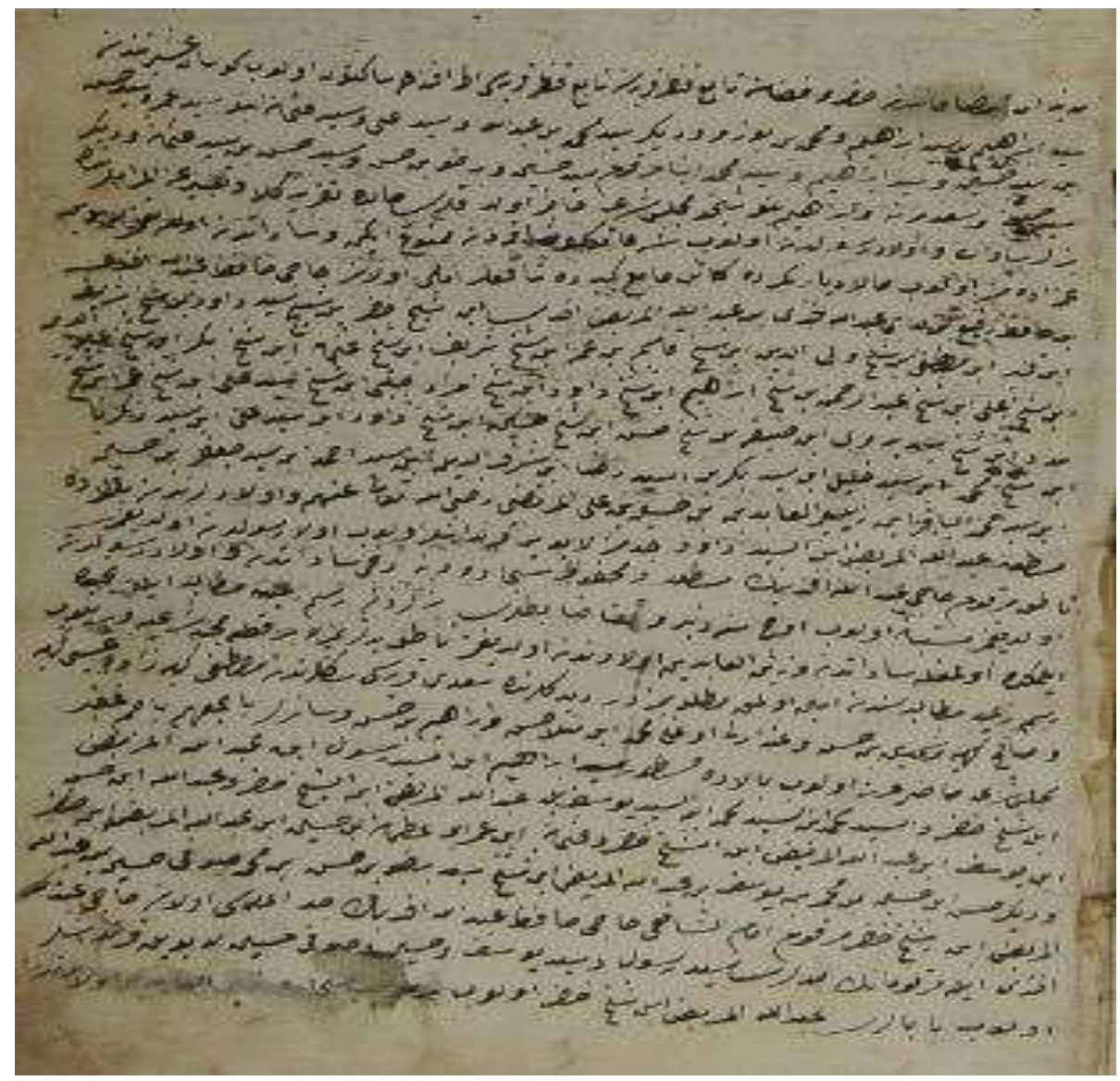

Belge 4: Kantar köyü civarından bazı seyyidler, ehl-i örf'ten bazı kimselerin kendilerinden usulsüz vergi talebinde bulunduğunu iddia ederek çok sayıda şahitle seyyidliklerini ispatlamaları ve vergi talebinin usulsüz olduğunu tescil ettirmeleri, bk. DŞS, 3760, 2a-2. Evâil-i Rebîü'levvel 1258 (12-21 Nisan 1842). 


\section{Sayyids in the Ottoman Social Life: The Case of Diyarbekir in the 18th and 19th Centuries}

\section{Extended Summary}

The generation of Fatıma, daughter of the Prophet Muhammad, and Ali who continue lineage of the Prophet Muhammad is entitled as sayyid and sheriff. Although there is widespread information that the Husaynis were called sayyids and the Hasenis as sheriff in the Ottoman Empire, it is not an accurate generalization. Because there was no clear distinction regarding the lineage of Hasan and Huseyin in this period. However, in the Ottoman Diyarbekir, the generation of both Hasan and Huseyin was entitled sayyid, and the term sheriff was not used. Sayyids are among the most important subjects of the Ottoman social history by their social roles and positions. The aim of this study was to shed light on the social life of the sayyids based on Diyarbekir court records and judgement records in the 18th and 19th centuries. In the study, it was determined that sayyids' visibility in social life was quite high depending on their social position and roles, and it was found out that the sayyids had a very effective presence in professional and social fields. Although Sayyids largely had a reputable and distinguished position in society, they had a lifestyle which was consistent with the spiritual responsibility they bore since they represented the lineage of the Prophet Muhammad.

During this period, it was understood that the sayyids were active in various professional fields, from professorship to cadets, tradesmen to state governorships. They have had an intense presence in judicial services, administrative duties and tradesmen, especially in religious services. However, they are among the notables of the society not only professionally but also in terms of their social roles and positions. Therefore, it can be said that sayyids are a respected and effective social group that is at the center of social life.

The findings of the research revealed that the title of sheriff was not used in Ottoman Diyarbakir. It revealed that the title of sayyid was used for the generation of Hasan and Huseyin. Therefore, there is no distinction between sayyids and sharifs according to being Hasenī and Huseynī. In addition, it has been determined that many women come from sayyid families, but generally not the titles of sayyide or sherife are used for them.

The professions performed by the sayyids during this period, their nicknames and titles indicated that they were generally in the middle and upper layers of the society. In financial terms, they are reflected in documents as more lender or creditors.

According to the information given in the documents, sayyids are mostly monogamous. It was determined that only one sayyid had two wives. Another point that draws attention is that no slave or concubine is included among the goods in 
the estate -except for an umm-i veled concubine who is in the estate of a sayyid who is in the position of governor of the state. A similar picture is encountered when looking at the documents other than the estate records on the subject. Here, too, there is only one person in a document that makes a purchase of a concubine in partnership with another - probably for a commercial purpose. Apart from this, no sayyids or sayyides who owned slaves or concubines were encountered. However, in the documents of the period, it was observed that many people had slaves and especially concubines. This is an important view that sayyids or sayyides did not lean towards employing slaves and acquiring concubines. The fact that the Quran has an important role encouraging people to free slaves and concubines and to give them their freedom.

The examined documents revealed that, in the event of a defendant of any of the sayyids, they were also brought in front of the Shariah court and tried. However, in this process, it has been understood that when there is a religious provision that needs to be brought to court, arrested, imprisoned, injured or executed, the duty and authority to execute it belongs to the nakibuleshrāf district governors. It has been revealed that the state attaches great importance to the sayyids as they represent the lineage of the Prophet. However, when their unjust actions were unfair, they were tried in equal status with other Muslims and non-Muslims in front of the law. The fact that sayyids, who are attributed a special value to them, are tried with an equal status with non-Muslims, especially when they come face to face with them, and when appropriate justice is ruled against them, is a striking view of the Ottoman social life and justice system.

It has been revealed that the sayyids are attributed a special value to the society as well as the state and that they are in a respectable position. However, in this period, it was also observed that some people subjected the sayyids to some unlawfulness from time to time from the ahl-i urf or the reaya. The most important of these is irregular interventions in trusteeship duties in foundations. Another lawlessness that came after this was that some of the people of the traditional customs tried to collect taxes from the sayyids illegally. During this period, some sayyids who were dealing with tradesmen had some difficulties while performing their profession. It was mostly caused by the unfair and unauthorized harassment of the sayyids because of the interests of some people doing the same job. Apart from these problems encountered in daily life and which can be considered ordinary due to the conditions of the period, it has been observed that there are almost no crimes such as extortion, murder, assault and theft against sayyids.

As it is mentioned, there are not many crimes against sayyids. However, during this period, the crimes the sayyids committed or were accused of were almost nonexistent. In other words, in this period, the sayyids were subjected to some unlawfulness, albeit a little. However, the crimes caused by the sayyids are much less than these. This is a remarkable view of sayyids' reliability.

Keywords: Islamic History, Sayyids, Ottoman Social Life, Sheriff, Diyarbekir. 